\title{
Snow water equivalent in the Alps as seen by gridded data sets, CMIP5 and CORDEX climate models
}

\author{
Silvia Terzago ${ }^{1}$, Jost von Hardenberg ${ }^{1}$, Elisa Palazzi ${ }^{1}$, and Antonello Provenzale ${ }^{2}$ \\ ${ }^{1}$ Institute of Atmospheric Sciences and Climate, National Research Council of Italy, Corso Fiume 4, Turin, Italy \\ ${ }^{2}$ Institute of Geosciences and Earth Resources, National Research Council of Italy, Via Moruzzi 1, Pisa, Italy \\ Correspondence to: Silvia Terzago (s.terzago@isac.cnr.it)
}

Received: 5 December 2016 - Discussion started: 26 January 2017

Revised: 23 May 2017 - Accepted: 24 May 2017 - Published: 10 July 2017

\begin{abstract}
The estimate of the current and future conditions of snow resources in mountain areas would require reliable, kilometre-resolution, regional-observation-based gridded data sets and climate models capable of properly representing snow processes and snow-climate interactions. At the moment, the development of such tools is hampered by the sparseness of station-based reference observations. In past decades passive microwave remote sensing and reanalysis products have mainly been used to infer information on the snow water equivalent distribution. However, the investigation has usually been limited to flat terrains as the reliability of these products in mountain areas is poorly characterized.

This work considers the available snow water equivalent data sets from remote sensing and from reanalyses for the greater Alpine region (GAR), and explores their ability to provide a coherent view of the snow water equivalent distribution and climatology in this area. Further we analyse the simulations from the latest-generation regional and global climate models (RCMs, GCMs), participating in the Coordinated Regional Climate Downscaling Experiment over the European domain (EURO-CORDEX) and in the Fifth Coupled Model Intercomparison Project (CMIP5) respectively. We evaluate their reliability in reproducing the main drivers of snow processes - near-surface air temperature and precipitation - against the observational data set EOBS, and compare the snow water equivalent climatology with the remote sensing and reanalysis data sets previously considered. We critically discuss the model limitations in the historical period and we explore their potential in providing reliable future projections.
\end{abstract}

The results of the analysis show that the time-averaged spatial distribution of snow water equivalent and the amplitude of its annual cycle are reproduced quite differently by the different remote sensing and reanalysis data sets, which in fact exhibit a large spread around the ensemble mean. We find that GCMs at spatial resolutions equal to or finer than $1.25^{\circ}$ longitude are in closer agreement with the ensemble mean of satellite and reanalysis products in terms of root mean square error and standard deviation than lowerresolution GCMs. The set of regional climate models from the EURO-CORDEX ensemble provides estimates of snow water equivalent at $0.11^{\circ}$ resolution that are locally much larger than those indicated by the gridded data sets, and only in a few cases are these differences smoothed out when snow water equivalent is spatially averaged over the entire Alpine domain. ERA-Interim-driven RCM simulations show an annual snow cycle that is comparable in amplitude to those provided by the reference data sets, while GCM-driven RCMs present a large positive bias. RCMs and higher-resolution GCM simulations are used to provide an estimate of the snow reduction expected by the mid-21st century (RCP 8.5 scenario) compared to the historical climatology, with the main purpose of highlighting the limits of our current knowledge and the need for developing more reliable snow simulations.

\section{Introduction}

The increase in surface temperatures (IPCC, 2013) has relevant consequences for high-elevation regions, where snow is a dominant climatic feature (Diffenbaugh et al., 2013; Barnett et al., 2005). The shift of the $0^{\circ} \mathrm{C}$ isotherm to higher 
elevations results in a decrease in the solid-to-total precipitation ratio in mid- and low-altitude mountain areas, where temperatures are currently close to the melting point (Hantel et al., 2012; Serquet et al., 2011; Beniston, 2003). In addition, higher temperatures may result in earlier snowmelt and shortening of the snow cover duration. Finally, snow cover and its local-scale variability affect climate at larger scales through the snow-albedo feedback (Scherrer et al., 2012).

Changes in mountain snowpack are expected to have implications on water availability, in particular on the timing of the seasonal run-off, likely characterized in the future by earlier spring or even winter discharge and reduced flows in summer and autumn (Beniston and Stoffel, 2014; Diffenbaugh et al., 2013; Barnett et al., 2005), and on the timing of the groundwater recharge. Similarly, changes in the seasonality, amount and duration of snow cover can have significant impacts on mountain economies for winter tourism (Beniston et al., 2011; Rixen et al., 2011) and on mountain ecosystems, including high-altitude vegetation (Körner, 2003) and the population dynamics of animal species that depend on snow resources (Imperio et al., 2013).

For these reasons, reliable regional estimates of current and future expected changes in snow cover are essential to develop adaptation and management strategies. Detailed studies on the recent and projected impacts of global warming in snow-dominated regions are necessary to inform future management of water resources (Beniston and Stoffel, 2014; Stewart, 2009; Barnett et al., 2005) and to preserve essential ecosystem services for millions of people living in downstream areas. For such applications, the uncertainties associated with the future snow projections must be carefully estimated and the reliability of the model results should be assessed.

In order to evaluate state-of-the-art global and regional climate models (GCMs, RCMs) and their future projections, as well as to improve the representation of snow processes in such models, reliable data sets are required, possibly at high spatial resolution and representing the local climate characteristics in orographically complex areas. However, the density of surface stations measuring snow is currently insufficient to develop a global, reliable gridded snow water equivalent data set based on in situ measurements, thus calling for the use of alternative sources of information on snow depth and mass, derived from remote sensing observations and reanalyses (Mudryk et al., 2015).

Satellite measurements have been shown to provide a reliable picture of the global snow cover extent at a spatial resolution of a few hundred metres (Brown et al., 2010; Hall and Riggs, 2007), while the estimations of snow depth and snow water equivalent from satellite are typically calculated at spatial scales of $25 \mathrm{~km}$ and are more challenging (Salzmann et al., 2014, see also Sect. 2). Global reanalyses provide snow water equivalent fields at horizontal resolutions that are comparable ( $\sim 30 \mathrm{~km}$ in the zonal direction) or coarser than satellite products. Some reanalyses, such as ERA-Interim (Dee et al., 2011) and NCEP-CFSR (Saha et al., 2010), assimilate surface snow depth measurements and satellite snow cover extent while others, such as MERRA (Rienecker et al., 2011) and 20CR (Compo et al., 2011), are not constrained by snow measurements and thus rely on the capability of their landsurface model component to estimate snow fields. Overall, one must be aware of the very different meanings of "high resolution" in remote sensing studies, where spatial resolution can be of a few metres, and in climate modelling and/or gridded data sets, where the highest spatial resolutions that can be usually achieved are of the order of a few kilometres.

To date, a few studies have investigated the accuracy of satellite-based and reanalysis snow water equivalent (SNW) data sets against available observations, and very little is known about their performance in mountain areas. Clifford (2010), for example, compared the long-term global snow water equivalent climatology provided by the National Snow and Ice Data Center (NSIDC-SNW, Armstrong et al., 2005), derived from passive microwave instruments, to the ERA40 reanalysis (Uppala et al., 2005) and to the output of the global climate model HadCM3 (Gordon et al., 2000; Collins et al., 2001). The largest differences between the three data sets were found for the Himalayas and for the west coast of North America, likely owing to heterogeneity of the subgrid topography. Globally, the GCM and the reanalysis were found to be in better agreement with each other than with the satellite product. The GCM and reanalysis fields displayed a similar climatological annual cycle in the Northern Hemisphere, a thick snow depth over Eurasia and a thin one over Siberia, while the satellite data indicated a thin snowpack in Eurasia and a thick one in Siberia, overestimating snow depth with respect to the available ground observations. Another recent study by Mudryk et al. (2015) widened the analysis of Clifford (2010) by investigating additional SNW global data sets derived from satellite and surface measurements (GlobSnow, Takala et al., 2011), from reanalyses (ERA-Interim/Land and MERRA) and from land-surface models driven by meteorological forcing. The spread among these products was found to be lowest in midlatitude boreal regions while their temporal correlation was highest, likely owing to the fact that snow cover is generally ubiquitous during the cold season and the atmospheric circulation (midlatitude winter cyclones) is well reproduced in the models. The largest spread was found in the Arctic and alpine regions, where reanalyses are poorly constrained by surface observations and the uncertainty in the meteorological forcing is higher. Alpine regions are characterized by additional complexity due to steep elevation gradients and subgrid surface heterogeneities that are difficult to represent in land-surface models.

The present work is devoted to reviewing the available snow data sets and quantitatively assessing the uncertainties in the estimation of the snow water equivalent in alpine environment. First, we expand the study by Mudryk et al. (2015) by including additional global SNW gridded data sets obtained from remote sensing and reanalyses, and we explore 
how these data sets represent the snow climatology over the greater Alpine region (GAR). Based on this analysis, we critically discuss the performance of state-of-the-art SNW products in an orographically complex area and we provide an estimate of the inter-data set spread in the Alps. These results are used as a reference for evaluating the state-of-theart climate models participating in the two major coordinated global and regional climate modelling experiments: the 5th Coupled Model Intercomparison Project (CMIP5, Taylor et al., 2012), providing global simulations at spatial resolution on the order of $100 \mathrm{~km}$, and the Coordinated Regional Climate Downscaling Experiment over the European domain (EURO-CORDEX, Jacob et al., 2014), providing regional simulations up to $12 \mathrm{~km}$ spatial resolution. For each model, we assess its ability to represent (i) the main drivers of snow processes, i.e. surface air temperature and precipitation, compared to the observational data set EOBS and (ii) the snow water equivalent climatology compared to the ensemble mean of the satellite and reanalysis data sets.

At the present state of affairs, i.e. without sufficient knowledge of real surface snow conditions, it is not possible to make any statement on the reliability of future snow water equivalent projections at mountain range scale. In this study, without attempting to assess how snow resources will evolve in the future, we show how model uncertainty and spread found in the historical period project into the future to (i) assess the overall agreement in relative snow changes (i.e. changes relative to each model's historical climatology) and (ii) discuss the differences in the amplitude of the relative snow changes projected for the mid-21st century under a high-range emission scenario (RCP 8.5) by coarse- (CMIP5) and fine-scale (EURO-CORDEX) models.

The paper is organized as follows: Sect. 2 introduces the data sets used for the analysis; Sect. 3 describes the area of study, discusses the representation of orography in the current generation regional and global climate models and summarizes the methodology employed for the data processing; Sect. 4 reports the results in terms of (i) snowpack distribution in remote sensing products, reanalyses and climate model simulations over the greater Alpine region during the last decades, (ii) inter-data set spread in the representation of the annual cycle of snow water equivalent and (iii) inter-data set spread in the representation of the snow changes expected by the mid-21st century in the RCP8.5 scenario. Sections 5 and 6 provide a general discussion of the results in relation to other studies and conclude the paper.

\section{Data sets}

\subsection{Remote sensing products}

Satellite sensors can provide a reliable picture of the snow cover extent, but the estimation of the snow water equivalent is more challenging. Passive microwave methods are based on the difference in brightness temperatures in two microwave channels, typically corresponding to frequencies of 18 and $36 \mathrm{GHz}$. These methods are unable to detect very thin snow layers (i.e. less thick than $15 \mathrm{~mm}$, Hancock et al., 2013) and suffer from saturation above $\sim 250 \mathrm{~mm}$ SNW (Clifford, 2010). Snow estimates from satellite are also affected by metamorphism of snow grains and snowmelt: large, platelike crystals increase the scattering of radiation from the surface, and a shallow but dense snowpack can be misinterpreted as a thick one. Owing to its high emissivity, liquid water, either within the snowpack or at the air-snow interface, overwhelms the scattering by the snow cover and can cause an underestimation of the snow thickness. Additionally, melt-refreeze processes during the melt season can cause spurious snow peak values (Hancock et al., 2013). The horizontal resolution of satellite brightness temperature measurements makes the snow estimates extremely challenging in complex terrain owing to the heterogeneity of snow properties at subgrid scale. An eloquent example is the European Space Agency GlobSnow product in which the alpine regions are masked out because of intrinsic poorer performance and limited possibility to validate the snow estimates with surface observations (Takala et al., 2011).

Notwithstanding these limitations, satellite products are commonly used to evaluate SNW as they offer a global view of snowpack characteristics for several decades. In the present study we consider the following satellite products available for our study area:

- Global Monthly EASE-Grid Snow Water Equivalent Climatology (Armstrong et al., 2005) provided by the National Snow and Ice Data Center (NSIDC-SNW): this data set includes global, monthly satellite-derived snow water equivalent data from November 1978 through May 2007 at $25 \mathrm{~km}$ resolution (Equal-Area Scalable Earth Grid, EASE-Grid). The snow water equivalent is derived from a Scanning Multichannel Microwave Radiometer (SMMR) and selected Special Sensor Microwave/Imagers (SSM/I).

- AMSR-E/Aqua Monthly L3 Global Snow Water Equivalent (level-3) monthly data (Tedesco et al., 2004) from the Advanced Microwave Scanning Radiometer - Earth Observing System (AMSR-E) instrument on the NASA Earth Observing System (EOS) Aqua satellite. This data set contains SNW data and quality assurance flags mapped to $25 \mathrm{~km}$ EASE-Grids from 2002 to 2011.

NSIDC-SNW data have been evaluated over Russia using snow observations from the period 1979-2000 for March only, showing an average $12 \mathrm{~mm}$ bias, which means a bias of $10 \%$ or less if the mean SNW is $120 \mathrm{~mm}$ or higher (Gan et al., 2014). The evaluation of the AMSR-E SNW daily product in complex topography (Mackenzie River basin, Canada) against in situ snow depth observations showed similar results, a mean absolute error ranging from $12 \mathrm{~mm}$ in 
the early winter season to $50 \mathrm{~mm}$ in the late winter season (Tong and Velicogna, 2010). The differences among the two satellite products over the Alpine region in terms of average snow water equivalent during the overlapping period have been analysed and discussed in Sect. 4.1.1, Fig. 2f.

\subsection{Reanalyses}

A clear advantage of reanalysis products over observationbased data is that they provide global, physically consistent estimates of all atmospheric and land-surface fields of interest, mostly constrained by observations. The reliability of reanalyses is related to the density of the assimilated observations; thus it depends on the location, the time period and the variable considered. Reanalysis products, for example, are known to be poorly constrained by surface measurements in mountain areas where their uncertainty is larger than in other regions. Precipitation is treated differently in different reanalyses: in some cases it is a prognostic variable, i.e. it is generated by the atmospheric general circulation model and it is not constrained by observations (i.e. MERRA reanalysis, Rienecker et al., 2011); in other cases it is a prescribed forcing derived from global precipitation data sets (as in the case of CFSR and ERA-Interim/Land reanalyses). The reanalysis products considered in the present study are as follows:

- Climate Forecast System Reanalysis (CFSR, Saha et al., 2010) by the National Center for Environmental Prediction (NCEP) is a global, high-resolution, coupled atmosphere-ocean-land-surface-sea-ice system reanalysis covering the period 1979-2009 and providing, among other variables, SNW fields at horizontal resolution of $0.3125^{\circ}(\sim 38 \mathrm{~km}$ at the Equator). CFSR uses two sets of observed global precipitation analyses as precipitation forcing, namely CMAP (a 5-day mean precipitation data set at $2.5^{\circ}$ latitude-longitude grid) and CPC (daily gauge analysis at 0.5 degree lat-lon over land). CFSR snow fields are simulated by the landsurface model Noah and constrained by the CFSR snow analysis. The snow analysis is based on the SNODEP model (Kopp and Kiess, 1996), which integrates surface observations, SSM/I-based detection algorithms and the NESDIS IMS Northern Hemisphere snow cover, based on in situ and satellite data (Meng et al., 2012; Saha et al., 2010). Snow analyses are used to limit the upper and lower boundaries of Noah fields, which cannot be more than twice as large or less than half of the value provided by the analysis.

- Modern Era-Retrospective analysis for Research and Applications (MERRA, Rienecker et al., 2011) by the National Aeronautics and Space Administration (NASA) is a global atmospheric reanalysis generated through the Goddard Earth Observing System Model (GEOS-5) atmospheric general circulation model and an atmospheric data assimilation system. MERRA cov- ers the time period from 1979 to the present and uses a grid of $1 / 2^{\circ}$ latitude and $2 / 3^{\circ}$ longitude with 72 vertical levels. Its land-surface model, Catchment (Koster et al., 2000), includes an intermediate complexity snow scheme with up to three snow layers describing snow accumulation, melting, refreezing and compaction in response to meteorological forcings (Stieglitz et al., 2001).

- ERA-Interim/Land reanalysis by the European Centre for Medium-Range Weather Forecasts (ECMWF) is a global reanalysis of land-surface parameters at $\sim 80 \mathrm{~km}$ spatial resolution covering the period 1979-2010 (Balsamo et al., 2013). ERA-Interim/Land is the result of offline simulations performed with the improved landsurface model HTESSEL (Balsamo et al., 2009), which was forced by the meteorological fields from ERAInterim (Dee et al., 2011) and precipitation adjustments based on GPCP v2.1. ERA-Interim/Land rescales ERAInterim precipitation estimates on the Global Precipitation Climatology Project (GPCP) data to remove possible biases and introduce a constraint to the observations at a monthly timescale (Balsamo et al., 2015). In fact, in the Alps ERA-Interim/Land has been found to reduce the dry bias present in ERA-Interim (see Fig. $\mathrm{S} 1$ of the supplementary material). At large scales, the correction on snowfall has been found to be small, owing to an overall good representation in the original ERA-Interim reanalysis (Brun et al., 2013). In ERAInterim/Land snow density and snow depth are not constrained by data assimilation owing to limited availability of surface observations. In this way the accuracy of these variables relies purely on the capability of the HTESSEL land-surface model to correctly reproduce the real fields. ERA-Interim/Land has been proven to provide good quality land snow mass analyses, owing mainly to the improvements in the single layer snow scheme, with enhanced parameterizations of snow density and revised formulations for the subgrid snow cover fraction and snow albedo (Balsamo et al., 2015; Dutra et al., 2010).

- 20th Century Reanalysis version 2 (20CR v2, Compo et al., 2011) by the NOAA Earth System Research Laboratory (ESRL) Physical Sciences Division and the University of Colorado CIRES Climate Diagnostics Center provides a synoptic-observation-based estimate of global tropospheric variability spanning the time period from 1871 to 2008 . It is derived using only surface pressure observations and prescribing monthly SST and seaice distributions as boundary conditions for the atmosphere (Compo et al., 2011). SNW fields are available at a spatial resolution of $\sim 1.875^{\circ}(\sim 200 \mathrm{~km}$ in the zonal direction). 


\subsection{Global climate models}

Global climate models (GCMs) are the main tools available to explore climate processes and feedbacks at global scales, and to make projections for future climate change scenarios. Owing to coarse-grid limitations, current GCMs resolve explicitly only the main snow processes while the snow physics at subgrid scale is parameterized. In such conditions, the snow schemes used in GCMs are strongly simplified: they often treat snowpack as a single-layer over the ground surface and small-scale processes such as the refreezing of melted water within the snowpack and snow metamorphism are not properly taken into account (Steger et al., 2013).

Thanks to the availability of increasing computing resources it has been possible to run models at finer and finer spatial resolutions, thus permitting a more accurate representation of the topography in orographically complex areas (Davini et al., 2017; Sabin et al., 2013). Increased spatial resolution implies a more detailed view of the atmospheric forcings relevant for the mountain snowpack dynamics, i.e. altitudinal temperature gradients, precipitation distribution and phase, downward radiation, and the important physical processes could be better represented. As an example, the variable-resolution Laboratoire Meteorologie Dynamique (LMD) global climate model has been successfully employed to test the impact of the horizontal resolution on the representation of the monsoon over southern Asia (Sabin et al., 2013). They showed that the enhanced-resolution simulation at about $35 \mathrm{~km}$ greatly improves the representation of circulation features, the monsoon flow and the precipitation patterns with respect to the standard resolution model.

In the present study we consider the global climate models included in the CMIP5 archive (http://www.cmip-pcmdi. llnl.gov/cmip5), available in January 2015, which provide the SNW variable at monthly resolution (Table 1) during both the historical period (1850-2005) and the projection period (2006-2100) under the Representative Concentration Pathways scenario RCP8.5 (Moss et al., 2010). We consider the ensemble member r1i1p1 for all models except for EC-Earth (Hazeleger et al., 2012) for which the SNW data were not stored in the CMIP5 archive and for which we used the ensemble member r8ilp1. The spatial resolution varies from model to model in a range from 0.75 to $3.75^{\circ}$ longitude $(\sim 80$ to $400 \mathrm{~km}$ in the zonal direction; see Table 1).

\subsection{Regional climate models}

Dynamical downscaling of global climate models and reanalyses through regional models can potentially provide valuable information on the mountain cryosphere. Regional climate models are currently run at horizontal resolutions ranging from $50 \mathrm{~km}$ up to a few kilometres, allowing for a more refined representation of mountain topography and altitudinal gradients with respect to global models. Similarly to GCMs, RCM snow schemes are strongly simplified with re- spect to dedicated snowpack models (Steger et al., 2013), so their main added value is to reproduce snow processes in high-elevation areas, which are simply not represented in coarse grid GCMs.

In this work we consider all the RCMs participating in the EURO-CORDEX regional climate model experiment (Kotlarski et al., 2014) and providing the snow water equivalent variable at monthly resolution at the finest available spatial resolution, i.e. $0.11^{\circ}$ (Table 2). We evaluate the ERAInterim-driven runs, available for five models at the time we downloaded the data set in October 2016, in order to assess the RCM bias when the RCM is driven by a realistic atmospheric forcing. Three models show non-reliable trends (characterized by continuous snow accumulation and no melting) in a limited number of pixels - possibly areas masked as glaciers. As this feature introduces an error in the surface water budget and hampers the calculation of SNW spatial averages over the GAR, we retained only two RCMs out of the five to further investigate the historical and future simulations under the RCP 8.5 scenario (see Sect. 4.1.3 for details). Specifically one, the COSMO Climate version of Local Model (CCLM, Rockel et al., 2008) provides simulations driven by several different GCMs (namely EC-Earth, CNRM-CM5, HadGEM2-ES and MPIESM-LR), and thus it can be used to investigate the uncertainty in the snow estimate coming from the large-scale driver. The other, REMO2009, provides simulations driven by the MPI-ESM-LR global climate model.

\subsection{Observational data sets of air temperature and precipitation}

The ability of climate models to properly reproduce snow water equivalent depends on the accuracy of their surface snow schemes and on the reliability of the atmospheric fields forcing the snow schemes. Near-surface air temperature (TAS) and precipitation (PR) climatologies provided by the reanalyses and the climate models considered in this study are validated against two gridded observational data sets. Along the line of previous studies (Kotlarski et al., 2014) we consider the daily gridded EOBS data set (version 13, Haylock et al., 2008) at $0.25^{\circ}$ resolution, based on the European Climate Assessment and Data set station measurements.

In addition to this established and widely used reference, a second observational data set specifically developed for the Alpine region, HISTALP (Auer et al., 2007; Chimani et al., 2011), is analysed for comparison. HISTALP provides monthly temperature and precipitation fields at $0.08^{\circ}$ spatial resolution, and is based on surface measurements. Owing to its higher spatial resolution, HISTALP can explore such variables in finer detail with respect to EOBS. 
Table 1. Snow water equivalent data sets, including remote sensing products, reanalyses and CMIP5 global climate models used in this study. For each of these we report the land-surface model (LSM, when it applies), the spatial/spectral horizontal resolution and the relevant references. CMIP5 models with horizontal resolution equal to or finer than $1.25^{\circ}$ longitude are highlighted in bold.

\begin{tabular}{|c|c|c|c|c|}
\hline Model & Institution & LSM & Res. $\left[{ }^{\circ}\right.$ lon]/Sp.Res & Reference \\
\hline NSIDC-SNW & National Snow and Ice Data Center & - & $25 \mathrm{~km}$ & Armstrong et al. (2005) \\
\hline AMSR-E & National Snow and Ice Data Center & - & $25 \mathrm{~km}$ & Tedesco et al. (2004) \\
\hline CFSR & US National Centers for Environmental Prediction & Noah & 0.3125 & Saha et al. (2010) \\
\hline MERRA & US National Aeronautics and Space Administration & Catchment LSM & 0.67 & Rienecker et al. (2011) \\
\hline ERA-Interim/Land & European Centre for Medium-Range Weather Forecasts & HTESSEL & 0.7 & Balsamo et al. (2013) \\
\hline 20th Century Reanalysis & NOAA Earth System Research Laboratory & Noah & 1.875 & Compo et al. (2011) \\
\hline CMCC-CM & Euro-Mediterranean Centre for Climate Change & ECHAM5 & $\mathbf{0 . 7 5} / \mathrm{T} 159$ & Scoccimarro et al. (2011) \\
\hline EC-Earth & EC-Earth Consortium & HTESSEL & $\mathbf{1 . 1 2 5} / \mathrm{T} 159$ & Hazeleger et al. (2012) \\
\hline BCC-CSM1-1-M & Beijing Climate Center, China & BCC_AVIM1.0 & $\mathbf{1 . 1 2 5} / \mathrm{T} 106$ & Wu et al. (2013) \\
\hline MRI-CGCM3 & Meteorological Research Institute, Japan & HAL & $\mathbf{1 . 1 2 5} / \mathrm{T} 159$ & Yukimoto et al. (2012) \\
\hline CESM1-BGC & National Center for Atmospheric Research & CLM4 & 1.25 & Hurrell et al. (2013) \\
\hline CESM1-CAM5 & National Center for Atmospheric Research & CLM4 & 1.25 & Hurrell et al. (2013) \\
\hline CESM1-FASTCHEM & National Center for Atmospheric Research & CLM4 & 1.25 & Hurrell et al. (2013) \\
\hline CCSM4 & National Center for Atmospheric Research & CLM4 & 1.25 & Gent et al. (2011) \\
\hline CNRM-CM5 & Centre National de Recherches Météorologiques & ISBA & $1.4 / \mathrm{T} 127$ & Voldoire et al. (2013) \\
\hline ACCESS1-0 & CSIRO/BOM, Australia & MOSES2 & $1.875 / \mathrm{N} 96$ & Bi et al. (2013) \\
\hline ACCESS1-3 & CSIRO/BOM, Australia & CABLE1.0 & $1.875 / \mathrm{N} 96$ & Bi et al. (2013) \\
\hline CMCC-CMS & Euro-Mediterranean Centre for Climate Change & ECHAM5 & $1.875 / \mathrm{T} 63$ & Scoccimarro et al. (2011) \\
\hline CSIRO-Mk3-6-0 & CSIRO, Australia & MOSES II & $1.875 / \mathrm{T} 63$ & Collier et al. (2011) \\
\hline HadGEM2-AO & Met Office Hadley Centre & MOSES II & $1.875 / \mathrm{N} 96$ & Collins et al. (2011) \\
\hline HadGEM2-CC & Met Office Hadley Centre & MOSES II & $1.875 / \mathrm{N} 96$ & Collins et al. (2011) \\
\hline HadGEM2-ES & Met Office Hadley Centre & MOSES II & $1.875 / \mathrm{N} 96$ & Collins et al. (2011) \\
\hline MPI-ESM-LR & Max Planck Institute for Meteorology & JSBACH & $1.875 / \mathrm{T} 63$ & Giorgetta et al. (2013) \\
\hline MPI-ESM-MR & Max Planck Institute for Meteorology & JSBACH & $1.875 / \mathrm{T} 63$ & Giorgetta et al. (2013) \\
\hline MPI-ESM-P & Max Planck Institute for Meteorology & JSBACH & $1.875 / \mathrm{T} 63$ & Giorgetta et al. (2013) \\
\hline INM-CM4 & Institute for Numerical Mathematics & INM & 2.0 & Volodin et al. (2010) \\
\hline CESM1-WACCM & National Center for Atmospheric Research & CAM & 2.5 & Hurrell et al. (2013) \\
\hline GFDL-CM3 & NOAA Geophysical Fluid Dynamics Laboratory & LM3 & 2.5 & Donner et al. (2011) \\
\hline GFDL-ESM2G & NOAA Geophysical Fluid Dynamics Laboratory & LM3 & 2.5 & Dunne et al. (2012) \\
\hline GFDL-ESM2M & NOAA Geophysical Fluid Dynamics Laboratory & LM3 & 2.5 & Dunne et al. (2012) \\
\hline GFDL-CM2p1 & NOAA Geophysical Fluid Dynamics Laboratory & LM2 & 2.5 & Delworth et al. (2006) \\
\hline GISS-E2-H-CC & NASA Goddard Institute for Space Studies & GISS LSM & 2.5 & Schmidt et al. (2006) \\
\hline GISS-E2-H & NASA Goddard Institute for Space Studies & GISS LSM & 2.5 & Schmidt et al. (2006) \\
\hline GISS-E2-R-CC & NASA Goddard Institute for Space Studies & GISS LSM & 2.5 & Schmidt et al. (2006) \\
\hline GISS-E2-R & NASA Goddard Institute for Space Studies & GISS LSM & 2.5 & Schmidt et al. (2006) \\
\hline NorESM1-ME & Norwegian Climate Centre & CLM4 & 2.5 & Bentsen et al. (2013) \\
\hline NorESM1-M & Norwegian Climate Centre & CLM4 & 2.5 & Bentsen et al. (2013) \\
\hline BNU-ESM & Beijing Normal University, China & BNU-CoLM3 & $2.8125 / \mathrm{T} 42$ & $*$ \\
\hline CanESM2 & Canadian Centre for Climate Modelling and Analysis & CLASS & $2.8125 / \mathrm{T} 63$ & Arora et al. (2011) \\
\hline FGOALS-g2 & LASG/CESS, China & CLM3 & 2.8125 & Li et al. (2013) \\
\hline FIO-ESM & The First Institute of Oceanography, China & CLM3.5 & $2.8125 / \mathrm{T} 42$ & Qiao et al. (2013) \\
\hline HadCM3 & Met Office Hadley Centre & MOSES I & $3.75 / \mathrm{N} 48$ & Johns et al. (2003) \\
\hline
\end{tabular}

* Reference is http://esg.bnu.edu.cn/BNU_ESM_webs/htmls/index.html.

Table 2. EURO-CORDEX regional climate models providing ERA-Interim-driven runs for the snow water equivalent variable at $0.11^{\circ}$ spatial resolution considered in this study. For each of model we also report the land-surface model (LSM), the number of available GCM-driven runs and the reference.

\begin{tabular}{lllll}
\hline Model & Institution & LSM & $\begin{array}{l}\text { Ensemble } \\
\text { members }\end{array}$ & Reference \\
\hline CCLM4-8-17 & CLM Community & Terra-ML & 4 & Rockel et al. (2008) \\
ALADIN53 & Centre National de Recherches Météorologiques & ISBA & - & Farda et al. (2010) \\
HIRHAM5 & Danish Meteorological Institute & Hagemann (2002) & 1 & Christensen et al. (2007) \\
RACMO22E & Royal Netherlands Meteorological Institute & HTESSEL & 2 & Van Meijgaard et al. (2012) \\
REMO2009 & Climate Service Center & Hagemann (2002) & 1 & Jacob and Podzun (1997) \\
\hline
\end{tabular}




\section{Domain and methods}

The study domain is the greater Alpine region (Auer et al., 2007), extending in the range $4-19^{\circ} \mathrm{E}, 43-49^{\circ} \mathrm{N}$ (Fig. 1a). The complex orography of the area and the heterogeneous pattern of steep slopes and valleys hamper the representation of climate features from both an observational and a modelling point of view. As an example, Fig. $1 \mathrm{~b}$ points out how the topography is represented in the $1 \mathrm{~km}$ GLOBE digital elevation model (Hastings and Dunbar, 1999), in the CORDEX ERA-Interim-driven regional climate models and in the CMIP5 global climate models, in terms of median, 5th and 95th percentiles of the distribution of elevation. The median elevation is well reproduced by all models while the lowest and highest elevations are progressively cut out as the spatial resolution of the model coarsens. While RCMs are closer to the expected values, global climate models, including those with the finest spatial resolution, do not properly take into account elevations above $1500 \mathrm{~m}$ a.s.l. in the GAR. This limitation has to be considered when analysing GCM outputs over mountain areas since the world reproduced by the global models has a smooth orography and simplified physical processes.

In this paper we explore the degree of agreement (i) among the reference data sets illustrated in Sect. 2.1 and 2.2, (ii) of the CORDEX and CMIP5 models compared to the ensemble mean of the reference data sets and (iii) between the different climate model ensembles, by inspecting the December to April (DJFMA) mean TAS, PR and SNW climatologies.

The model performance with respect to the reference snow water equivalent data sets is quantified using Taylor diagrams, which provide a concise statistical summary of how well patterns match a given reference in terms of their linear correlation $(R)$, root mean square difference (RMSE), and ratio of their variances (NSD) (Taylor, 2001). In order to compare point by point data sets built on different coordinate reference systems and with different spatial resolutions, all data sets are reprojected onto a common grid. The ERA-Interim/Land $0.7^{\circ}$ longitude grid is chosen because of its intermediate resolution between global and regional climate models. Global climate models are also evaluated at their own resolution, comparing each model to remote sensing products and reanalyses upscaled at the climate model grid. This second approach allows the impact of the horizontal resolution on the performance of coarse-scale climate models to be reduced. Spatial interpolations are performed via conservative remapping (Jones, 1999), using the Climate Data Operators software (CDO, 2015).

Assessments of the SNW characteristics at the scale of the mountain range (Figs. 6 and 7) are obtained by spatially averaging the snow water equivalent over all areas above $1000 \mathrm{~m}$ a.s.l. in the GAR. To take into account the mismatch between the model topography and the real one, we use the data sets at their native resolution and weight the values by the fraction of each grid cell at elevation above
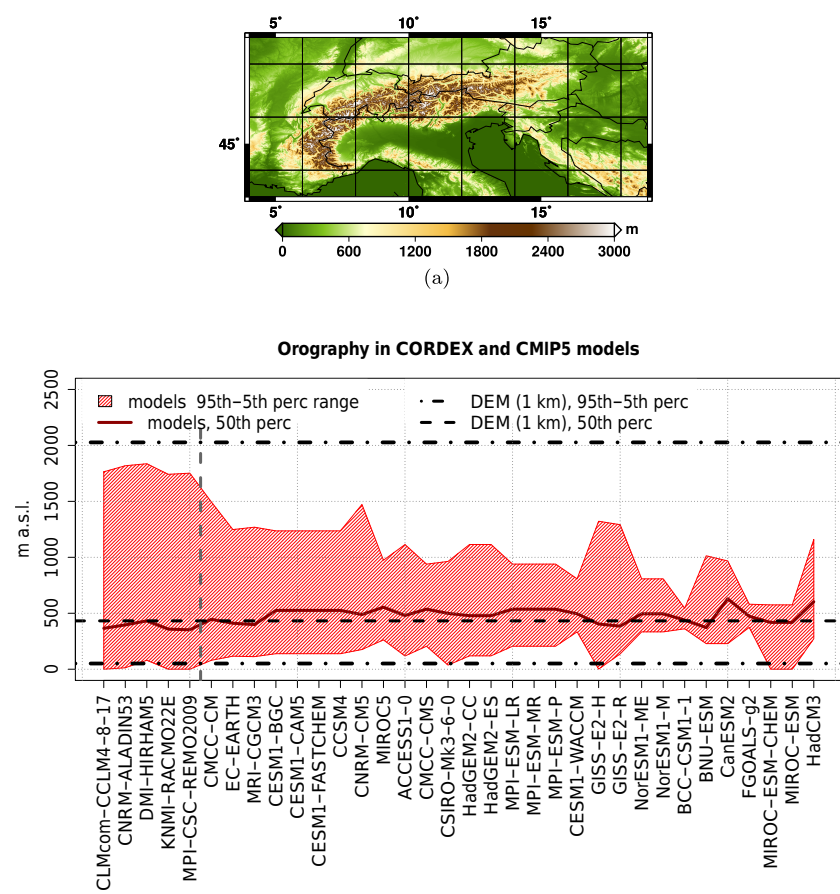

(b)

Figure 1. (a) Orography of the greater Alpine region $\left(4-19^{\circ} \mathrm{E}\right.$; $43-49^{\circ} \mathrm{N}$ ) as in the GLOBE $1 \mathrm{~km}$ digital elevation model (DEM). (b) The 95th (dash-dotted), 50th (dashed) and 5th (dash-dotted) percentiles of the elevation distribution in the DEM compared to the corresponding values obtained from the CORDEX and CMIP5 model orographies. RCM and GCM models are ordered along the $x$-axis from finest to coarsest spatial resolution. RCMs and GCMs are separated by a vertical dashed line.

$1000 \mathrm{~m}$ a.s.l as provided by the $1 \mathrm{~km}$ GLOBE (Hastings and Dunbar, 1999) digital elevation model; then the weighted values are spatially averaged over the domain of interest, the greater Alpine region. This procedure can be used to compare data sets characterized by very different spatial resolutions without introducing uncertainties due to regridding (see also Terzago et al., 2014, for further details).

\section{Results}

\subsection{The spatial distribution of snow water equivalent in gridded data sets}

\subsubsection{SNW in satellite products and reanalyses}

We first illustrate the spatial distribution of snow water equivalent in the satellite products and the reanalyses, hereafter referred to as the reference data sets, and we evaluate the differences among the reanalyses in relation to possible biases in the meteorological forcing. Figure 2 shows the multiannual mean (1980-2005) of near-surface air temperature (TAS), precipitation (PR) and SNW averaged (or accumu- 
lated in the case of PR) over the months from December to April. In order to facilitate the comparison we present the differences (or percent biases) with respect to a given data set, namely EOBS for TAS and PR and NSIDC-SNW for SNW, since it is available for a longer period (1980-2005) than the other satellite product, AMSR-E (2003-2011). All data sets are conservatively remapped onto a regular $0.25^{\circ}$ resolution grid. Biases are calculated over the period 1980-2005 except for AMSR-E, for which the period of overlap with the reference data set is 2003-2007.

Compared to EOBS, the alternative observational, highresolution climatology from HISTALP (Fig. 2d-e) presents a similar temperature distribution, drier conditions at high elevations and wetter conditions at low elevations. This comparison is reported to highlight the fact that uncertainties are larger in precipitation than in temperature estimates, especially in mountain areas, and also observational data sets can exhibit biases with respect to each other.

Focusing on the snow water equivalent distribution, the NSIDC-SNW climatology (Fig. 2c) shows maximum values of about $50 \mathrm{~kg} \mathrm{~m}^{-2}$ over the western Alps and $70 \mathrm{~kg} \mathrm{~m}^{-2}$ over the eastern Alps. If we consider the other satellite and reanalysis products we obtain a rather heterogeneous picture. AMSR-E (Fig. 2f) presents higher values in the western Alps and lower values in the eastern Alps compared to the NSIDCSNW.

CFSR (Fig. 2g-i) shows TAS and PR patterns that are similar to EOBS over the Alpine ridge and a SNW distribution that is similar to NSIDC-SNW. The similarity in the SNW range of variability is probably due to the fact that both products integrate the Special Sensor Microwave Imager (SSM/I) data but to different extents. NSIDC-SNW is specifically derived from the Special Sensor Microwave Imager (SSM/I) data. The CFSR snow output is mainly based on the Noah land-surface model first guess, and a daily snow analysis based on several inputs, including the Special Sensor Microwave Imager (SSM/I) data, is used to constrain the model first guess (Meng et al., 2012). The CFSR snow depth/SNW is limited in the upper and lower boundaries by the snow analysis (it cannot be larger than twice and lower than half the snow analysis) but the temporal evolution of snow depth and SNW is determined by the Noah model. As a consequence, the two SNW data sets lie in similar ranges of variability, but except for this feature they can be considered independent.

The MERRA Reanalysis (Fig. 2j-1) shows a thicker snowpack with respect to NSIDC-SNW, especially over the western Alps, as well as AMSR-E. The MERRA behaviour can be explained by a cold bias over that area, partly compensated by drier conditions over the Alpine peaks.

ERA-Interim/Land (Fig. 2m-o) shows the largest SNW values, with peaks exceeding NSIDC-SNW values by more than $200 \mathrm{~kg} \mathrm{~m}^{-2}$. The SNW bias is not directly explainable in terms of biases in temperature and precipitation, which indeed go towards the opposite direction (warmer and slightly drier with respect to EOBS). This result suggests that ERAInterim/Land high SNW values can be attributed to the snow scheme in use.

20CR (Fig. 2p-r) shows the lowest SNW values. Owing to its coarse spatial resolution, 20CR presents a warm and dry bias at high elevations and a cold and wet bias at low elevations, which in turn result in low snow accumulation and shallow snowpack over the mountain range. These simplified patterns can presumably be ascribed to an excessively smooth orography and highlight the limitations of the 20CR reanalysis in the representation of snow processes in mountain areas.

This analysis provides a quite heterogeneous picture of SNW and, despite the considerations on the biases of the drivers, it is not possible with current knowledge to ultimately define which product is closest to reality over the full GAR domain. For further analysis we disregard the 20CR reanalysis owing to its poor performance in this orographically complex region and the AMSR-E satellite product for its short period of availability. We consider as reference the mean of the other four data sets, i.e. NSIDCSNW, CFSR, MERRA and ERA-Interim/Land reanalyses. This multi-reference mean (MRM) is calculated after conservatively remapping all the data sets to the $0.7^{\circ}$ longitude ERA-Interim/Land grid.

\subsubsection{SNW in global climate models}

Here we discuss in detail the DJFMA TAS, PR and SNW climatologies provided by CMIP5 global climate models with spatial resolution equal to or finer than $1.25^{\circ}$ (Fig. 3); coarser resolution GCMs are discussed further in Sect 4.2.

CMIP5 model biases with respect to EOBS and NSIDCSNW references (Fig. 2a-c) are shown Fig. 3. The comparison period is 1980-2005. Of the four CESM-family models, namely CESM1-CAM5, CESM1-BGC, CESM1FASTCHEM and CCSM4, three models present very similar climatologies so here we consider only one of them, CESM1BGC, which is taken to be representative of CESM1FASTCHEM and CCSM4 (see Fig. S2 in the Supplement and Sect. 4.2 for further details).

GCMs with spatial resolution equal to or finer than $1.25^{\circ}$ show snow amounts which are comparable to those of the reference data sets over the greater Alpine region. Compared to NSIDC-SNW, the models CMCC-CM, EC-Earth and, to a smaller extent, MRI-CGCM3 and CESM1-CAM5, show thicker snowpack at the northern slope of the Alps and in Switzerland. A common feature of all data sets is a shallower snowpack over the eastern Alps, at the border between Italy and Austria. This spatial pattern, characterized by an east-west gradient, with shallower snowpack in the eastern Alps and thicker snowpack in the western Alps, more closely resembles that provided by the AMSR-E satellite product rather than that provided by NSIDC-SNW. 


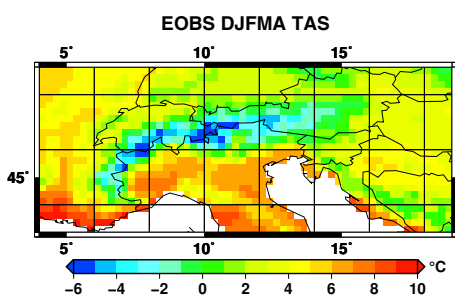

(a)

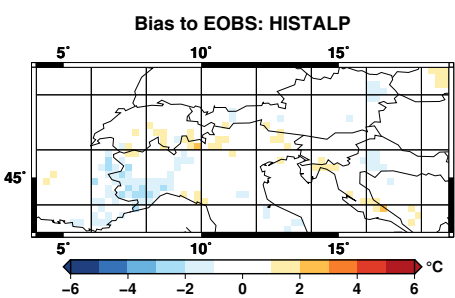

(d)

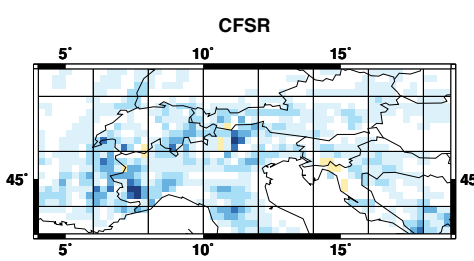

(g)

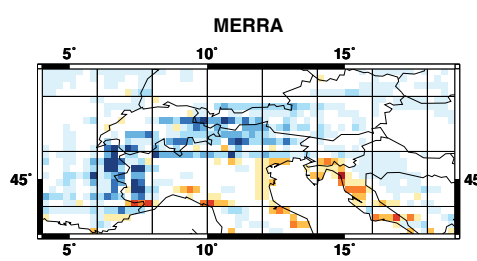

(j)

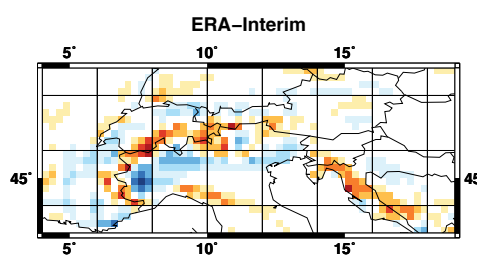

$(\mathrm{m})$

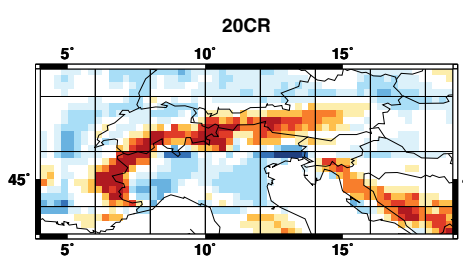

(p)

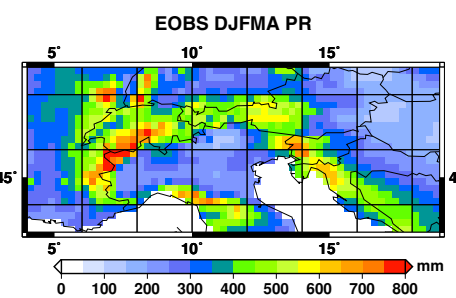

(b)

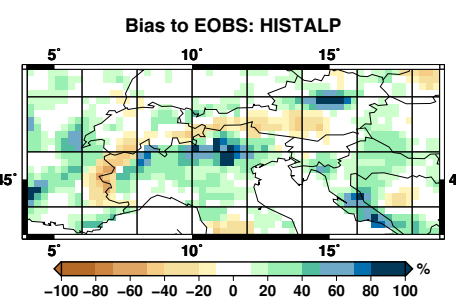

(e)

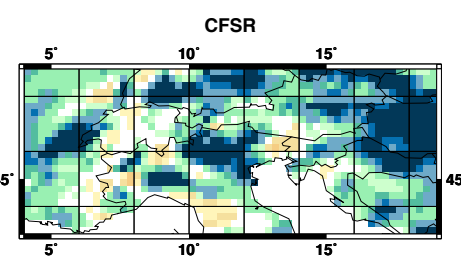

(h)

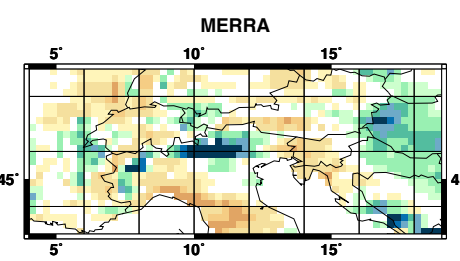

(k)

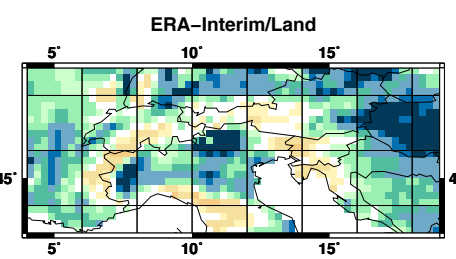

(n)

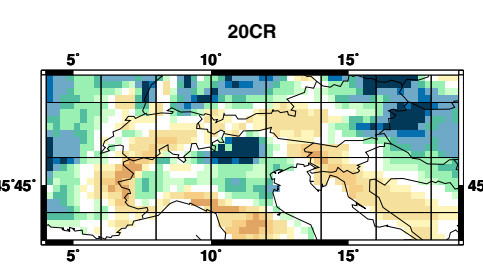

(q)

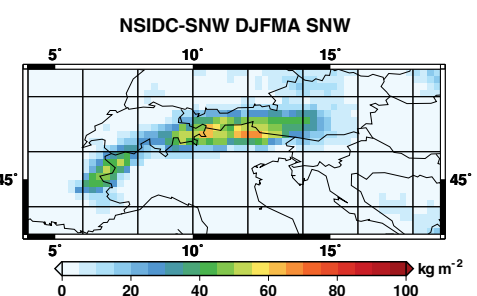

(c)

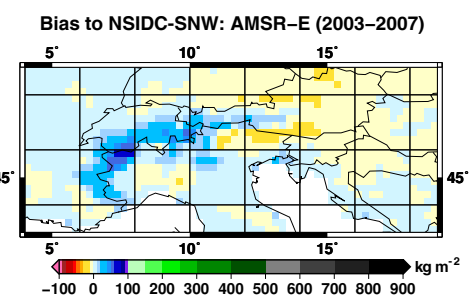

(f)

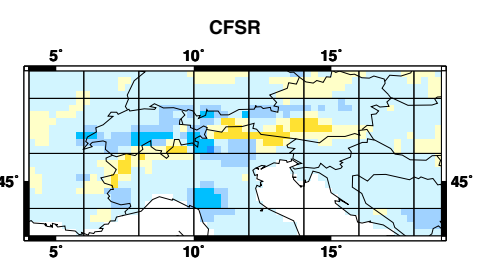

(i)

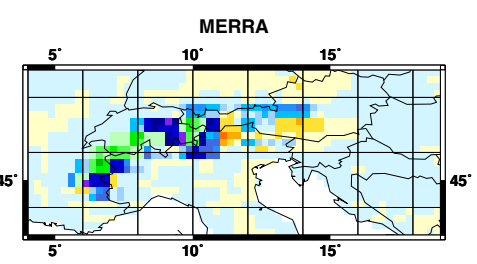

(1)

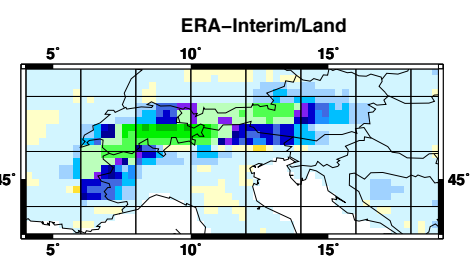

(o)

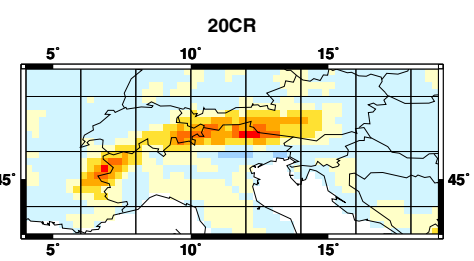

(r)

Figure 2. Multiannual mean (1980-2005) of the DJFMA average (a) air temperature, (b) total precipitation from EOBS observational data sets and (c) snow water equivalent from NSIDC-SNW. Panels from (d) to (r) represent the bias of HISTALP, AMSR-E and reanalyses with respect to EOBS and NSIDC-SNW data sets respectively. 


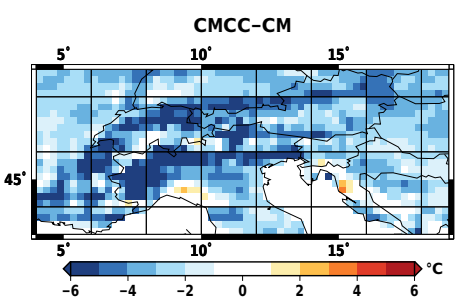

(a)

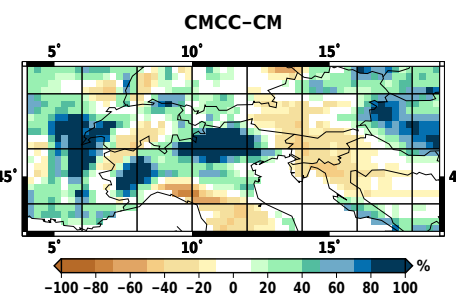

(b)

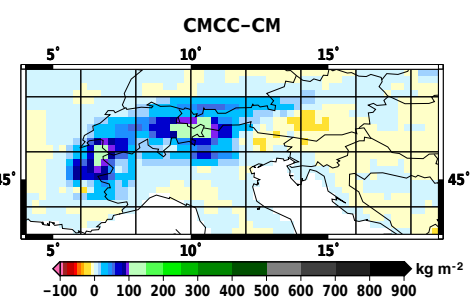

(c)

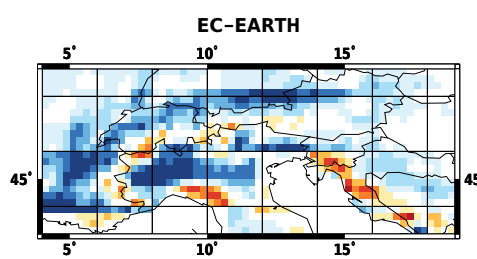

(d)

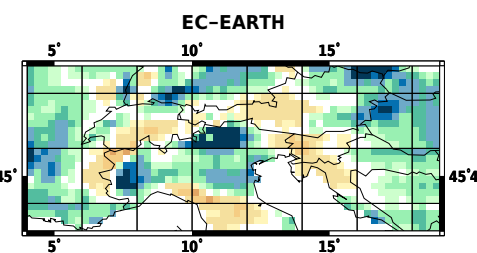

(e)

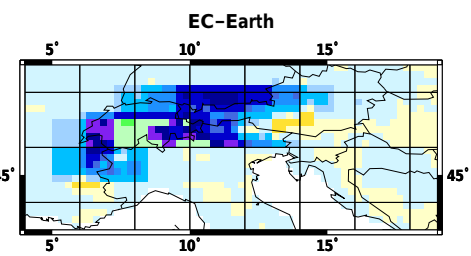

(f)

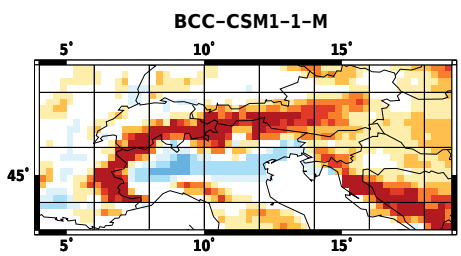

(g)

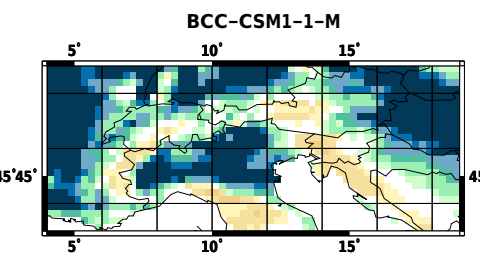

(h)

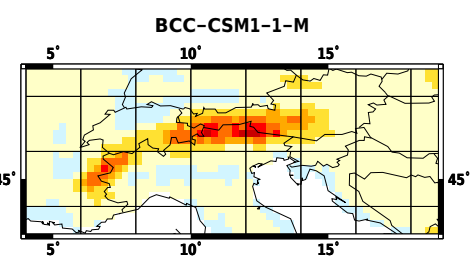

(i)

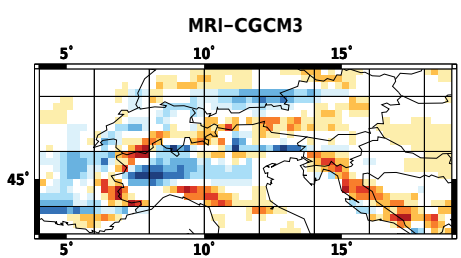

(j)

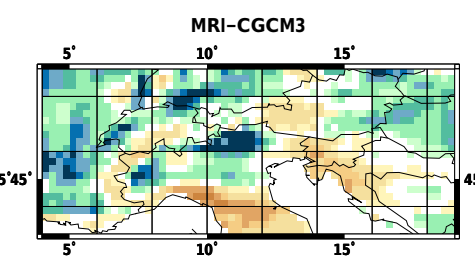

(k)

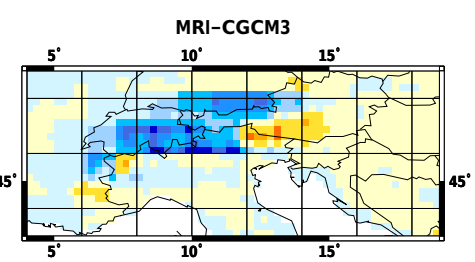

(1)

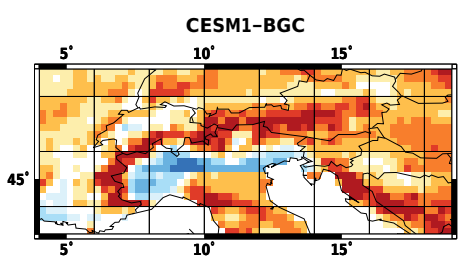

(m)

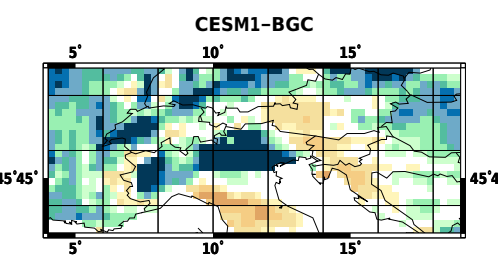

(n)

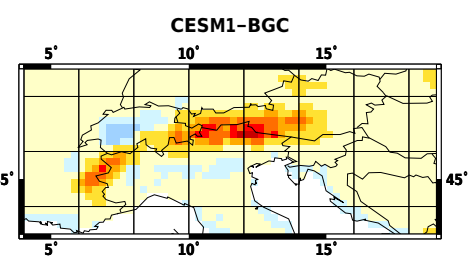

(o)

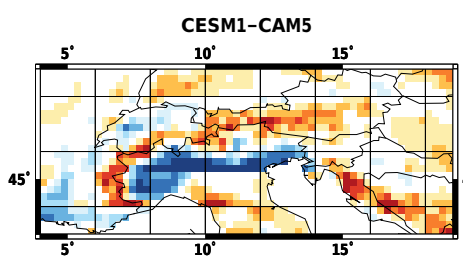

(p)

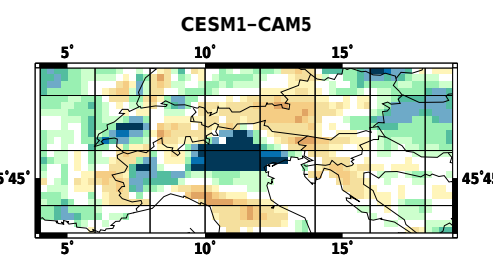

(q)

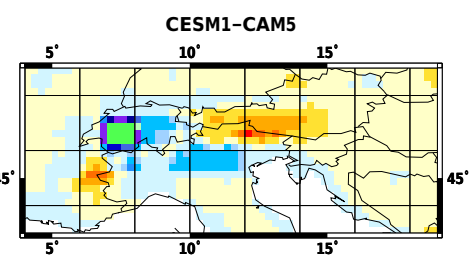

(r)

Figure 3. DJFMA (first column) air temperature, (second column) total precipitation and (third column) snow water equivalent biases of the CMIP5 global climate models with spatial resolution equal to or finer than $1.25^{\circ}$ longitude with respect to the EOBS and NSIDC-SNW climatologies reported in Fig. 2a, b, c. 
BCC-CSM1-1-M and CESM1-BGC show shallower snowpacks than NSIDC-SNW, and higher temperatures with respect to the observational data sets. In these cases the warm bias in the model can explain a less abundant snowpack.

From this analysis the precipitation bias over the Alpine ridge between the different high-resolution GCMs seems to be comparable. In fact, GCMs generally tend to a slight underestimation of winter precipitation at the ridges and to an overestimation at lower altitudes. This uniform behaviour in the precipitation pattern suggests that temperature can be the leading cause of biases in the estimation of surface snow water equivalent.

\subsubsection{SNW in regional climate models}

Figure 4 shows the biases of ERA-Interim-driven regional climate model DJFMA TAS as well as PR and SNW climatologies with respect to the EOBS and NSIDC-SNW references, all averaged over the common period 1990-2005.

All RCMs show SNW amounts several hundreds of $\mathrm{kg} \mathrm{m}^{-2}$ larger than any other reference data set (Fig. 2) at the mountain ridge and lower values at low elevations. Extremely high values (shown in black) are not reliable as they correspond to areas of continuous snow accumulation and no melting, possibly areas masked as glaciers in the models. Such grid points show artificially high erroneous, positive trends and they have to be discarded from the analysis. Despite these details, RCM snow estimates are much higher than those provided by the reference data sets, and these high values can be related to the fine representation of the orography that allows, in principle, for lower temperatures in high mountain areas that are not represented in coarse-scale reanalyses, for increased solid precipitation and longer snowpack duration.

In some cases the large SNW values in RCMs can be partly explained by cold biases (RACMO22E, ALADIN53) or wet biases (HIRHAM5) with respect to the observations. In other cases (CCLM4-8-17), despite remarkable biases in some parts of the domain, the atmospheric forcings in correspondence of the mountain ridge are in better agreement with observations and they do not show relevant deviations from the reference climatologies, so the differences have to be attributed to the snow scheme in use and/or to the finer representation of the topography.

From the analysis of RCMs we can conclude that higher spatial resolution allows areas of snow accumulation to be better separated and, consequently, to reproduce higher snow maxima in correspondence of mountain peaks.

For the CCLM4-8-17 and REMO2009 models, which display no issues in the snow accumulation trends, we also investigated the GCM-driven simulations (Table 2). GCMdriven CCLM4-8-17 climatologies have a stronger negative temperature bias (CNRM-CM5, EC-Earth, HadGEM2-ES) and/or stronger positive precipitation biases (CNRM-CM5, MPI-ESM-LR) with respect to the ERA-Interim-driven runs
(Fig. S3). These features result in thicker snow water equivalent. In the case of MPI-ESM-LR-driven REMO2009 the temperature bias is comparable while the precipitation bias is larger than for the ERA-Interim-driven runs. In conclusion, GCM-driven RCM simulations tend to inherit the biases already present in the driver GCM and to reflect them in SNW fields.

\subsection{Global view of SNW products}

In this section we provide a comprehensive view of all the previously considered SNW gridded data sets. The similarity of the SNW climatologies is quantified using the metrics of Taylor diagrams (Taylor, 2001). Figure 5a compares the spatial distribution of the DJFMA snow water equivalent, averaged over the period 1980-2005, for the multi-reference mean (MRM, mean of the four reference data sets CFRS, MERRA, ERA-Interim/Land and NSIDC-SNW) to which all other data sets are compared; the multi-model mean (MMM), mean of all 36 CMIP5 models; the multi-model mean of the CMIP5 models with spatial resolution equal to or finer than $1.25^{\circ}$ (MMM-HiRes, as in Terzago et al., 2014); the individual reference data sets; and the individual regional and global climate models.

First we compare data sets built on different coordinate reference systems and with different spatial resolutions by reprojecting all remote sensing products, reanalyses and climate model outputs onto a common grid, specifically the ERA-Interim/Land $0.7^{\circ}$ longitude grid. Figure 5 a provides an evaluation of the individual data sets with respect to the multi-reference mean, all resampled on the same $0.7^{\circ}$ grid. Reference data sets are generally highly correlated with the MRM $(R>0.85$ for all data sets except the coarsest 20CR). This feature is related to the dependence of the snow water equivalent on topography; i.e. these data sets represent larger SNW values at higher altitudes. Satellite products and the CFSR reanalysis are very close to each other, with lower variance with respect to the MRM. The MERRA reanalysis is close to the MRM, with comparable standard deviation and small RMSE. The ERA-Interim/Land and 20CR reanalyses show opposing behaviours in terms of normalized standard deviation, i.e. very high and very low respectively. ERA-Interim/Land has a wider statistical dispersion of SNW values and higher SNW peaks, clearly reflected in Fig. 2o, while 20CR has a narrow range of SNW values and a smooth SNW pattern (Fig. 2r).

Of the two RCMs considered, REMO2009 is in better agreement with the MRM in terms of RMSE and NSD. CCLM4-8-17 has a large normalized standard deviation, which is comparable to that found in ERA-Interim/Land. All GCM-driven simulations show higher variance with respect to the corresponding ERA-Interim-driven runs.

For GCMs, an important feature emerging from this analysis is that, on average, the ensemble mean of the highresolution models performs better in terms of standard de- 


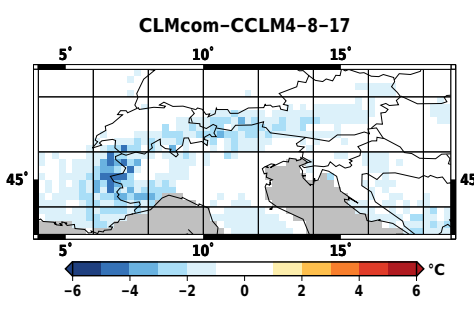

(a)

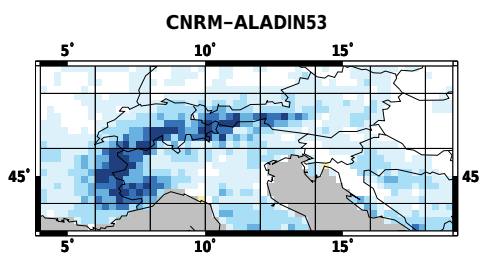

(d)

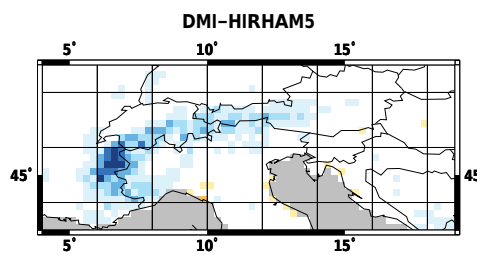

(g)

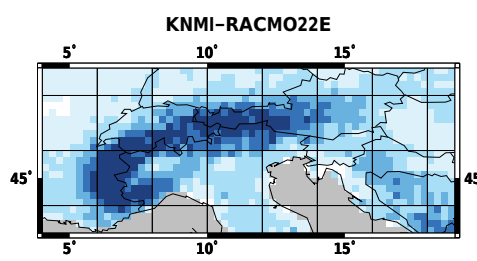

(j)

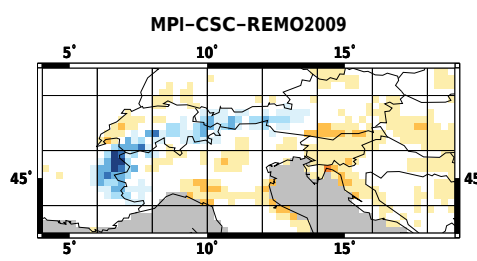

(m)

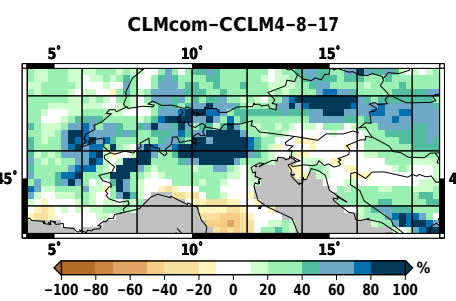

(b)

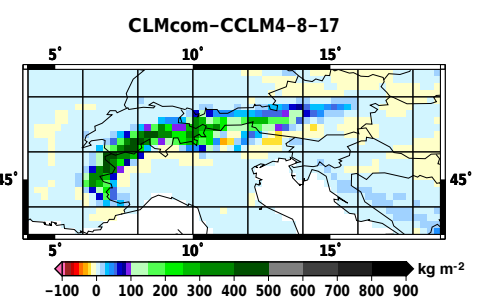

(c)

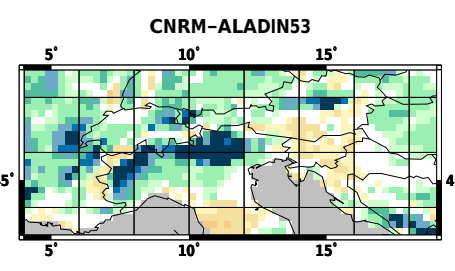

(e)

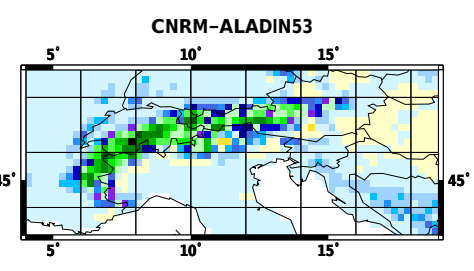

(f)

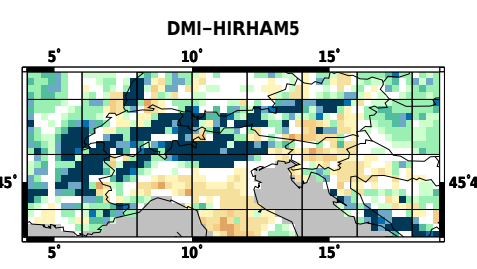

(h)

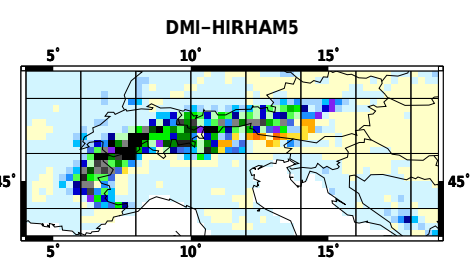

(i)

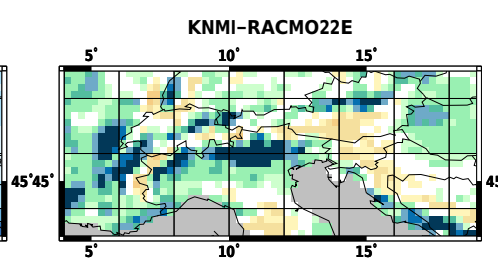

(k)

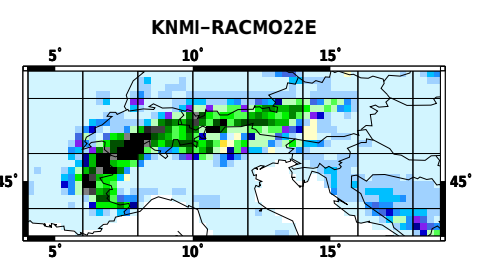

(l)

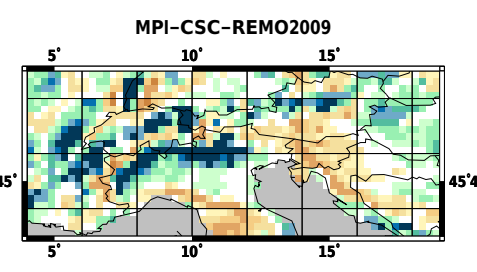

(n)

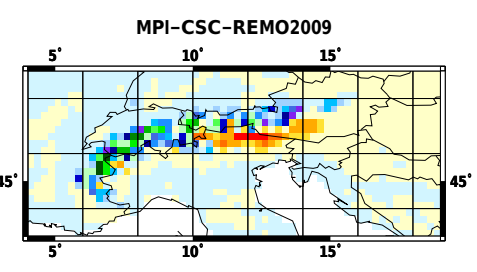

(o)

Figure 4. As in Fig. 3 but for the CORDEX ERA-Interim-driven RCM simulations, averaged over the period 1990-2005.

viation, root mean square difference and pattern correlation, with respect to the ensemble mean of all CMIP5 GCMs. This result highlights the importance of the horizontal resolution in simulating snowpack spatial patterns (Terzago et al., 2014).

An alternative approach has been devised to provide a fair comparison of the GCMs. Each GCM is compared to the MRM after having conservatively remapped each reference data set onto the individual GCM grid, so that the reference is reshaped each time according to the model resolution. This approach allows for a fair evaluation of each GCM on its own grid, regardless of its resolution. For the sake of clarity, we present the results relative to this approach by separately plotting the models with resolutions equal to or finer and coarser than $1.25^{\circ}$ (Fig. 5b). The clustering based on spatial resolution reveals that coarse resolution models generally have very high or very low standard deviation (please note that the CNRM-CM5 model lays outside the range of the plot). In such circumstances the ensemble mean of the models is the result of compensating extreme behaviours, and it 

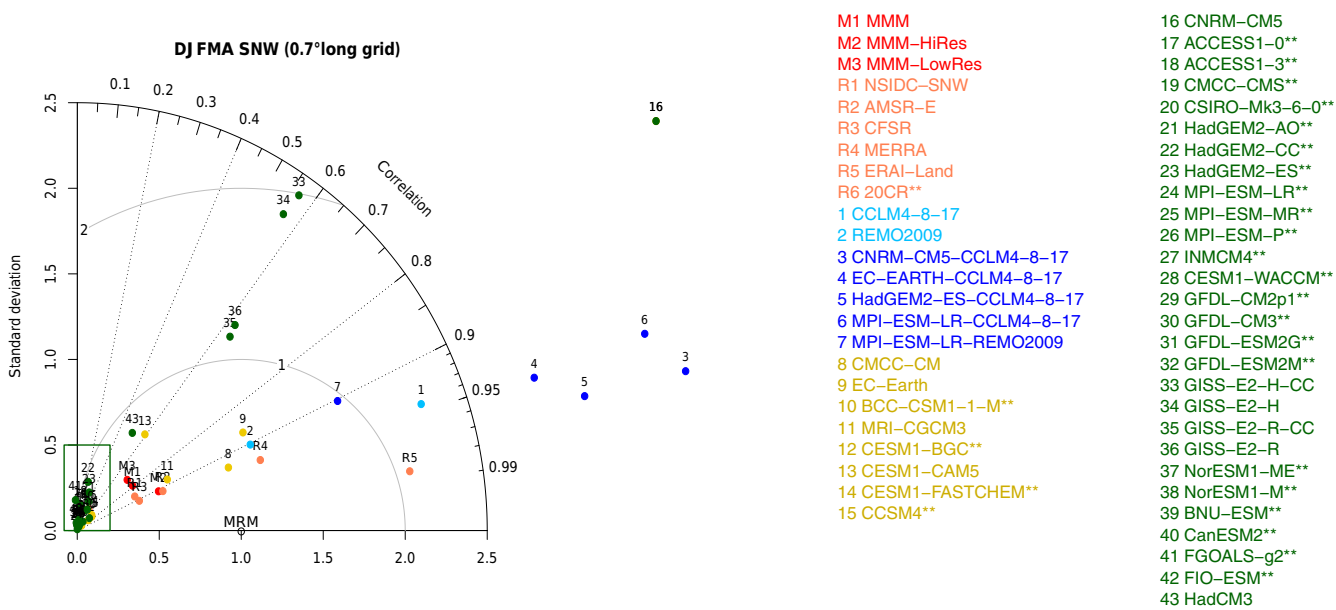

(a)
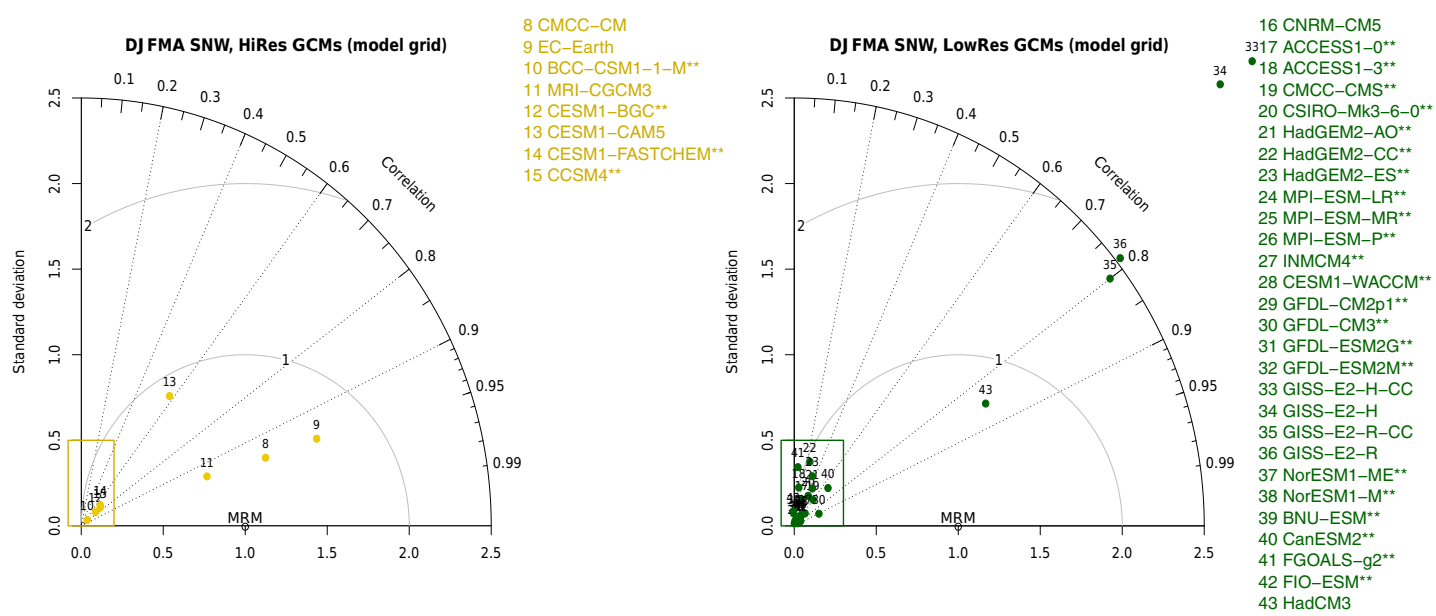

(b)

Figure 5. Taylor diagrams of the multiannual mean (1980-2005) of the DJFMA average snow water equivalent as described by climate models against the multi-reference mean $(\mathrm{MRM})$ : (a) all data sets are projected onto the same reference grid at $0.7^{\circ}$ lon; $(\mathbf{b})$ the climate models are kept at their original resolution and the reference data sets are remapped onto the grid of each model. Points included in the rectangles correspond to models highlighted with ** in the legend.

should be considered with caution. On the contrary, individual high-resolution GCMs are generally closer to the MRM and do not exhibit extreme features, constituting a more homogeneous ensemble.

Figure 5 provides information on the similarity of SNW climatologies and, indirectly, qualitative information on the degree of interdependency of the models belonging to the same "family". For example, among the previously mentioned four CESM-family models, namely CESM1-CAM5, CESM1-BGC, CESM1-FASTCHEM and CCSM4, three models show a high degree of similarity (Figure $5 \mathrm{~b}$ ). In the calculation of the MMM-HiRes, in order to limit the bias related to the interdependency of the models, out of these three similar models we retained only one, CESM1-BGC. In the following we will use the term "high-resolution GCMs" to indicate only the following six models: CMCC-CM, ECEarth, MRI-CGCM3, BCC-CSM1-1-M, CESM1-BGC and CESM1-CAM5. These models are further analysed in the following sections. The interdependency of lower-resolution GCMs is not clearly detectable from the Taylor diagram and it is not investigated further as these models are not the main focus of the paper, owing to their overall poor performance in the representation of SNW.

\subsection{Annual cycle of snow water equivalent}

In Fig. 6a-b we show the annual cycle of snow water equivalent as represented by the reference data sets and by the highresolution GCMs. The monthly SNW at elevations higher 
than $1000 \mathrm{~m}$ a.s.l is spatially averaged over the greater Alpine region and temporally averaged over the common period 1980-2005 (see Sect. 3 for details).

The annual cycle in the reference data sets displays a unimodal distribution, with the maximum occurring in different months from January to March for different data sets. The spread in the reference data sets is quite large, ranging from about $40 \mathrm{~kg} \mathrm{~m}^{-2}$ SNW peak in January in the NSIDCSNW satellite product to $150 \mathrm{~kg} \mathrm{~m}^{-2}$ SNW peak in March in ERA-Interim/Land. These two products have the most extreme behaviour. NSIDC-SNW and CFSR show a very similar annual cycle (and comparable spatial patterns), while MERRA presents intermediate values between these two and ERA-Interim/Land. The MRM peaks in February, at about $75 \mathrm{~kg} \mathrm{~m}^{-2}$. The spread among the high-resolution GCMs is also rather large, as it is for the reference data sets. Snow water equivalent maximum values range from $3 \mathrm{~kg} \mathrm{~m}^{-2}$ according to BCC-CSM1-1-M to about $90 \mathrm{~kg} \mathrm{~m}^{-2}$ according to EC-Earth. CESM1-BGC and BCC-CSM-1-1-M show very shallow SNW (few $\mathrm{kg} \mathrm{m}^{-2}$ ) throughout the year and a much shorter snow season, owing to a large positive bias in air temperature (Fig. 3g, m). CMCC-CM and EC-Earth display above-average values, with EC-Earth reproducing a snow cycle similar to ERA-Interim/Land but with lower amplitude. The similarity between EC-Earth and ERA-Interim/Land is likely related to the fact that they use the same land-surface model, HTESSEL (Hazeleger et al., 2012). As in the case of the MRM, the MMM-HiRes peaks in February but with lower SNW values of approximately $50 \mathrm{~kg} \mathrm{~m}^{-2}$. With respect to the reference ensemble mean, the GCM ensemble mean tends to underestimate SNW throughout the snow season.

An important outcome of this analysis is that the reference data sets exhibit a large spread in the Alps. As a consequence, any assessment based on the use of individual data sets within this ensemble and within this region should be taken with extreme caution.

Figure 6c shows a synthetic view of the SNW annual cycle as in the RCM simulations compared to the reference data sets and to GCMs. ERA-Interim-driven simulations provide similar results to the reference data sets. In particular the ERA-Interim-REMO2009 annual cycle is close to the ensemble mean of the reference data sets and the ERA-InterimCCLM4-8-17 annual cycle is close to that provided by ERAInterim/Land. Relatively larger snow water equivalent values by the CCLM4-8-17 model can be related to wetter conditions (Fig. 4a, b) which probably result in larger snow accumulation.

GCM-driven simulations overestimate the SNW annual cycle in comparison to their ERA-Interim-driven counterparts. REMO2009, when driven by MPI-ESM-LR GCM, provides SNW values close to the maximum values found in reference data sets, and CCLM-4-8-17, irrespective of the driving GCM, shows notably thicker snowpack than any reference data sets and/or GCM. The snow peak is about three times higher than the reference ensemble mean, up to almost twice the ERA-Interim-driven value, and it is shifted later in the snow season. Such an outcome reflects the biases inherent in the driving GCMs, which result in large errors in SNW estimates.

An important hint of this analysis is that despite the large differences in horizontal resolutions, the reference data sets, selected high-resolution GCMs and the ERA-Interim-driven RCMs provide comparable results in terms of SNW when the quantities are spatially averaged over the Alpine domain. Unfortunately the uncertainty on the SNW annual cycle as represented by these data sets is large, and conclusive statements on the accuracy of these SNW estimates require a reliable ground truth to validate the model results.

\subsection{Future changes in the annual cycle of SNW}

Figure 7a shows the projected annual cycle of snow water equivalent for the mid-21st century (2040-2065) in the RCP8.5 scenario compared to the historical annual cycle (1980-2005), according to the high-resolution CMIP5 models. Both the ensemble mean and the spread of GCMs are shown. The SNW peak is expected to reduce by more than $50 \%$ in the future, with respect to the historical multi-model mean. The uncertainty on the amplitude of the snow peak is, however, very large and the value depends upon the selected GCM. The spread in the percent changes of SNW according to the various models (Fig. 7b) reveals the degree of intermodel consistency. The largest uncertainty is found in summer months, i.e. when snow cover persists only at high altitudes, and it can be very shallow. EC-Earth shows a smaller reduction while all the other models predict almost complete snow loss, on average, over the Alpine region (not shown). The lowest reduction is found in December, when the projected decrease ranges between -20 and $-70 \%$ depending on the model.

For comparison we also analyse the projected changes in the annual SNW cycle according to the REMO2009 model and to the CCLM4-8-17 model driven by different GCMs (Fig. 7b). Interestingly, the percent SNW reduction according to RCMs, although still remarkable, is lower compared to CMIP5 GCMs, especially in the spring season. From February to April the percent SNW change reported by RCMs lies outside the range of variability of CMIP5 models. The robustness of this result should be verified by considering a larger RCM ensemble, as soon as additional RCM simulations become available. Figure $7 \mathrm{~b}$ also shows the influence of the driving GCM on SNW change. The spread among the different RCM simulations allows for an evaluation of the impact of the uncertainty due to the drivers of the snow changes, and its amplitude stresses the importance of performing ensemble analyses. 
SNW annual cycle - reference data sets

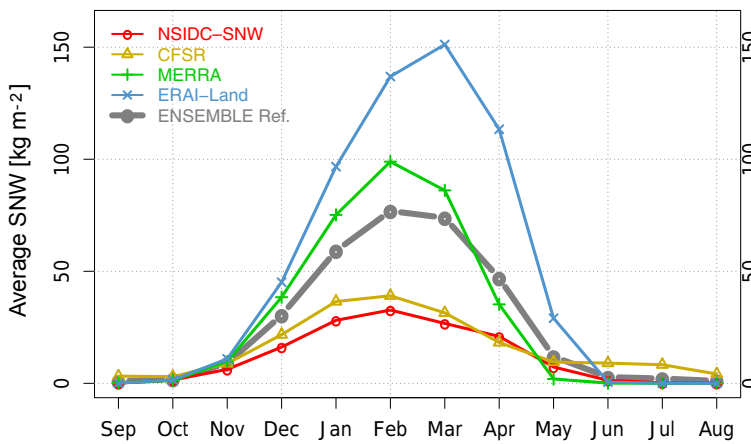

(a)
SNW annual cycle - high res. CMIP5 GCMs

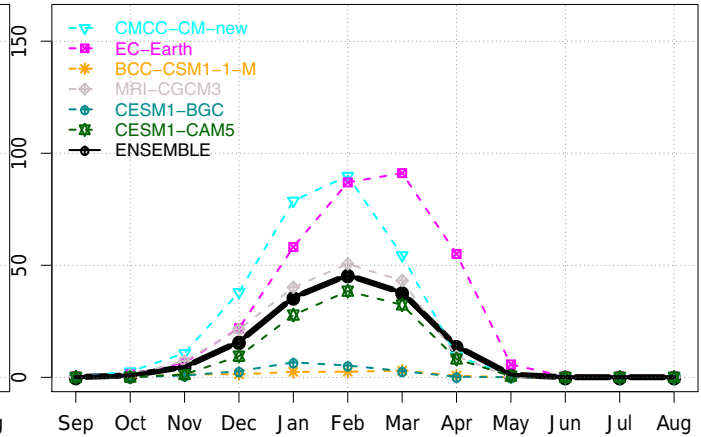

(b)

SNW annual cycle - CORDEX RCMs

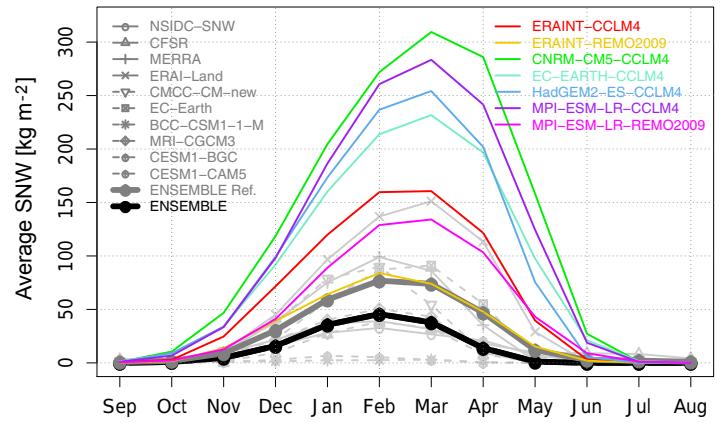

(c)

Figure 6. (a) Annual cycle of snow water equivalent in the reference data sets and (b) in CMIP5 high-resolution GCMs (spatial averages over areas above $1000 \mathrm{~m}$ a.s.l., temporal averages over the historical period 1980-2005). (c) Annual cycle in ERA-Interim-driven and GCM-driven regional climate model simulations, calculated over the period 1990-2005, in comparison to reference data sets and GCM simulations.

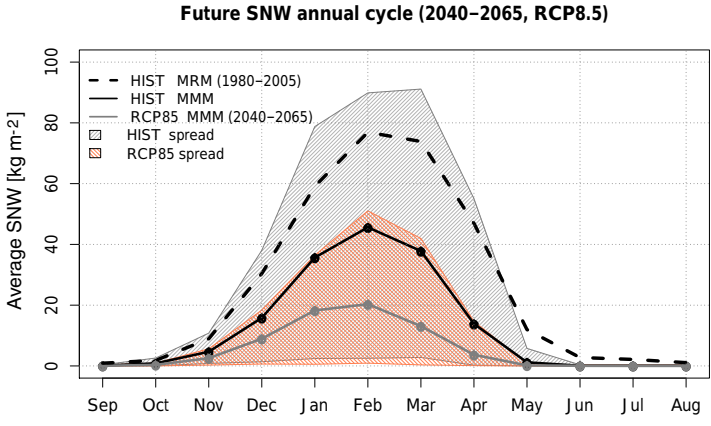

(a)

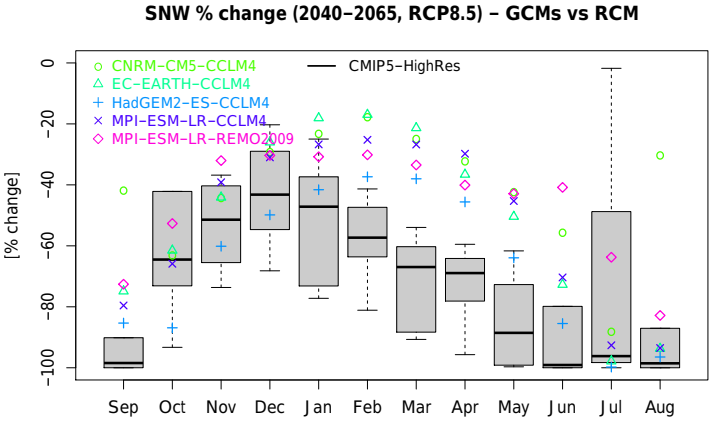

(b)

Figure 7. (a) Annual cycle of snow water equivalent expected by the mid-21st century in the RCP8.5 scenario compared to the baseline 19802005, as provided by the high-resolution CMIP5 models. (b) Percent change in snow water equivalent (2040-2065 average with respect to the baseline 1980-2005) as in the high-resolution CMIP5 GCMs (box plot) and RCM simulations.

\section{Discussion}

We tested the agreement and the uncertainties of the main snow water equivalent data sets, including remote sensing products, reanalyses, global and regional climate models, in reproducing the spatial pattern and the annual cycle of snow over the greater Alpine region. The spatial and temporal distribution of SNW is the result of the complex interaction of temperature, precipitation, solar radiation, wind and local geographical features. In mountain areas, in particular, meteoclimatic variables are characterized by high spatial variability depending, among other factors, on elevation, slope, as- 
pect and exposure to wind. The grid resolution of the remote sensing, reanalysis and climate model products is clearly insufficient to properly represent the spatial variability of snow water equivalent at small scales and at specific locations. For this reason, this study is aimed at analysing this ensemble of largely used data sets for regional assessment and quantifying their consistency and degree of agreement in reproducing the average snow conditions at their own resolution.

The reference data sets provide very different pictures of the multiannual mean DJFMA snow water equivalent in the greater Alpine region. The satellite-derived data sets and CFSR compare better with each other than with the other products. The two satellite products are based on similar algorithms but rely on different radiometer observations, and AMSR-E doubles the spatial resolution of SMMR and SSM/I. NSIDC-SNW and CFSR are likely more similar to each other because CFSR integrates snow analyses based on the same SSM/I observations used by the snow algorithm employed in NSIDC-SNW (Meng et al., 2012). It is worth stressing that CFSR is, of all the reanalyses considered in this study, the only one based on atmospheric-ocean-sea-ice coupling. It has the highest horizontal resolution and, as ERAInterim/Land, it is driven by observed rather than by forecasted precipitation fields. Interestingly, the analysis system used in CFSR for the atmosphere is similar to the one used in MERRA and although they use almost the same input data (Saha et al., 2010) they have rather dissimilar snow water equivalent climatologies. MERRA shows a snow distribution comparable to ERA-Interim/Land, likely because they assimilate observations from the same sources and they are run at similar horizontal resolutions. MERRA compares better to the MRM in terms of normalized standard deviation and RMSE, while ERA-Interim/Land displays higher snow values in agreement with the results obtained at the Northern Hemispheric scale (Mudryk et al., 2015) and over the HinduKush Karakoram Himalaya region (Terzago et al., 2014). The ERA-Interim/Land and 20CR reanalyses show opposing behaviour, i.e. very high and very low spatial variability respectively. In particular the 20CR snow water equivalent fields are extremely smooth with respect to all other data sets. This behaviour has been related to a strong warm bias in air temperature corresponding to the Alpine ridge.

The documented wide range of uncertainty has to be taken into account when using these snow data sets. Some discrepancies can be explained by possible biases in the drivers of snow processes, the use of different land-surface models, different snow schemes and different data assimilation methods, as discussed above. Additional weak points of these products are (i) their low spatial resolution with respect to what would be required to represent snowpack processes in mountain environments and (ii) the limited or null constraint by surface snow depth or snow water equivalent observations at high elevations (i.e. no snow assimilation). At the global scale, the spread over mountain regions has been estimated to be several times larger than over non-mountainous midlatitude regions (Mudryk et al., 2015). Reducing this gap through improvements in the horizontal resolution and enhanced assimilation of surface data will open new perspectives for a more reliable representation of snow resources in mountain regions at regional to global scales. Efforts have already been spent to provide reliable atmospheric fields to land-surface and snow schemes, for example improving precipitation in CFSR and ERA-Interim/Land. Further inclusion of a better resolved topography allows for a more realistic representation of snow processes and could mitigate the issue of upscaling surface measurements at the model grid in the assimilation process.

GCMs have evident limitations in representing the distribution of altitudes in the greater Alpine region, with the most resolved models underestimating the 95th percentile of the distribution by $500-800 \mathrm{~m}$. GCMs do not take into proper account elevations above 1500-2000 m a.s.l. which are simply not represented in most models (see also Fig. S4 for further details on the elevation ranges represented in each data set). On the other hand, the analysis of the CMIP5 GCMs reveals that models with spatial resolution finer or equal to $1.25^{\circ}$ are in better agreement with the ensemble mean of the reference data sets than the whole GCM ensemble. Compared to low-resolution models, the high-resolution models form a more homogeneous cluster with no extreme behaviour and a higher score (lower RMSE and relative standard deviation closer to one). Provided that high-resolution GCMs have different characteristics and different land-surface model components (Table 1), their better performance is likely due to the (relatively) finer spatial resolution. This analysis clearly indicates the added value of snow simulations at higher horizontal resolution, even for the typical resolutions of GCMs.

The EURO-CORDEX regional downscaling experiment further elucidates how horizontal resolution can affect the representation of the snow processes in mountain areas. The results from the currently available simulations at $0.11^{\circ}$ resolution (five ERA-Interim-driven models) show a much thicker average snowpack over the alpine ridge and shallower snowpack at low elevations with respect to the reference data set. This behaviour, related to the finer-resolution RCM, is sometimes smoothed out when snow water equivalent is spatially averaged over the Alpine domain. At the regional scale, the annual cycle represented by ERA-Interim-driven RCMs results comparable to those found in the reference data sets and in GCMs. Important deviations from the reference data sets arise in GCM-driven RCM simulations, owing to the biases inherent in the GCM forcing.

The influence of the single model bias with respect to the reference has been minimized by analysing the future change in snow water equivalent with respect to the historical mean, i.e. by considering anomalies. GCM projections agree in showing a strong reduction of snow resources by the mid-21st century in the RCP 8.5 scenario, especially in the spring season. The uncertainties on the amplitude of the snow water equivalent change are large, but the signal is coherent across all models. 
Future RCM projections show weaker snow reductions with respect to the coarser-scale high-resolution GCMs, especially in spring, when future snow projections appear particularly uncertain. While a few regional models can have limited representativeness of the whole EURO-CORDEX ensemble and a larger set of simulations has to be considered as soon as they become available, this analysis highlights the large discrepancy among the considered data sets over the historical period and calls for a reference observation-based product that could reliably represent the ground truth.

\section{Conclusions}

This study shows that the spatial and temporal distribution of snow water equivalent in the greater Alpine region (one of the most measured mountain regions in the world) is quite uncertain. The main available gridded snow water equivalent data sets are derived from remote sensing observations and reanalyses but they have never been properly validated in mountain regions owing to the limited availability of in situ snow observations. In this work, we compared such data sets to highlight the degree of agreement in the mean climatologies, to quantify their spread and assess the uncertainties associated with snow estimates. These data sets provide very different pictures of the snow spatial distribution and seasonal cycle. Of course, mountain regions have non-optimal conditions to test these coarse-grid data sets, as surface heterogeneity at subgrid scale is difficult to represent, both for remote sensing and reanalysis data. This argument enforces the evidence that we currently lack proper information on snowpack distribution at mountain range scale. Knowledge of the long-term variability of the snowpack at high spatial resolution and at mountain range scale is limited but necessary for climate studies, for calibrating/validating models, for data assimilation in the reanalysis products and for assessing seasonal water resources. In our opinion, improving the open availability and the exchange of in situ snow observations and developing gridded snow data sets representative of the ground truth in mountain regions is a priority for advancing cryospheric/hydrologic research in mountain environments.

A second method of improving snow estimates in mountain areas in both reanalyses and climate models is to pursue high-resolution simulations to allow for a better representation of the main drivers of the snow processes, i.e. temperature and precipitation patterns and their dependence on elevation. An increased horizontal resolution, and thus a more accurate representation of topography, allows for a better description of the spatial distribution and phase of precipitation and of altitudinal temperature gradients. New insights on this topic are expected by the High RESolution Model Intercomparison Project (Haarsma et al., 2016), the CMIP6endorsed coordinated experiment that will provide an ensemble of GCM runs at spatial resolutions significantly finer than the current generation CMIP5 models.
A further goal is the refinement of the representation of snowpack processes, which at the moment are drastically simplified, in global climate and earth system models (ESMs). This issue is being addressed by the ESM-SnowMIP initiative (van den Hurk et al., 2016, see also http://www.climate-cryosphere.org/activities/ targeted/esm-snowmip) through coordinated experiments to evaluate snow modules of large-scale climate models and quantify the required complexity to be represented in ESMs.

The present study contributes to these challenges by providing a picture of the main available snow products and measuring the related uncertainties in the Alpine environment. The relative assessment of the capability of satellitebased products, reanalyses, RCMs and GCMs in reproducing snowpack features provides important information to both model developers and to the community of users, allowing critical factors in the model components to be identified and raising awareness of the strengths and limitations of the available products.

Data availability. All the data sets used in this study are publicly accessible and were downloaded from the following websites: CMIP5 and CORDEX model simulations, https://esgf-data.dkrz.de/ projects/esgf-dkrz/; NSIDC Global Snow Water Equivalent climatology and AMSR-E products, https://nsidc.org/; CFSR reanalysis, https://rda.ucar.edu/; MERRA reanalysis, https://mirador.gsfc.nasa. gov/; ERA-Interim/Land reanalysis, http://apps.ecmwf.int; EOBS, http://www.ecad.eu; HISTALP, http://www.zamg.ac.at/histalp/.

\section{The Supplement related to this article is available online at https://doi.org/10.5194/tc-11-1625-2017-supplement.}

Competing interests. The authors declare that they have no conflict of interest.

Acknowledgements. This work has received funding from the European Union's Horizon 2020 research and innovation programme under Grant Agreements No. 641762 (ECOPOTENTIAL), No. 641816 (CRESCENDO) and No. 641727 (PRIMAVERA). This work was also supported by the Italian project of Interest NextData of the Italian Ministry for Education, University and Research. We acknowledge the World Climate Research Programme's Working Group on Coupled Modelling and Working Group on Regional Climate, which are responsible for CMIP5 and CORDEX, and we thank the climate modelling groups (listed in Tables 1 and 2) for producing and making available their model output. For CMIP the U.S. Department of Energy's Program for Climate Model Diagnosis and Intercomparison provides coordinating support and led development of software infrastructure in partnership with the Global Organization for Earth System Science Portals. We also acknowledge the EOBS data set from the EU-FP6 project ENSEMBLES (http://ensembles-eu.metoffice.com) and the data 
providers in the ECA\&D project (http://www.ecad.eu). We finally thank the two referees for their valuable comments which allowed us to significantly improve the paper.

Edited by: Xavier Fettweis

Reviewed by: Yves Cornet and one anonymous referee

\section{References}

Armstrong, R., Brodzik, M., Knowles, K., and Savoie, M.: Global Monthly EASE-Grid Snow Water Equivalent Climatology [1979-2005]. Boulder, Colorado USA: NASA National Snow and Ice Data Center Distributed Active Archive Center, 2005.

Arora, V., Scinocca, J., Boer, G., Christian, J., Denman, K., Flato, G., Kharin, V., Lee, W., and Merryfield, W.: Carbon emission limits required to satisfy future representative concentration pathways of greenhouse gases, Geophys. Res. Lett., 38, L05805, https://doi.org/10.1029/2010gl046270, 2011.

Auer, I., Böhm, R., Jurkovic, A., Lipa, W., Orlik, A., Potzmann, R., Schöner, W., Ungersböck, M., Matulla, C., Briffa, K., et al.: HISTALP-historical instrumental climatological surface time series of the Greater Alpine Region, Int. J. Climatol., 27, 17-46, 2007.

Balsamo, G., Beljaars, A., Scipal, K., Viterbo, P., van den Hurk, B., Hirschi, M., and Betts, A. K.: A revised hydrology for the ECMWF model: Verification from field site to terrestrial water storage and impact in the Integrated Forecast System, J. Hydrometeor., 10, 623-643, https://doi.org/10.1175/2008jhm1068.1, 2009.

Balsamo, G., Albergel, C., Beljaars, A., Boussetta, S., Brun, E., Cloke, H., Dee, D., Dutra, E., Muñoz-Sabater, J., Pappenberger, F., de Rosnay, P., Stockdale, T., and Vitart, F.: ERA-Interim/Land: a global land surface reanalysis data set, Hydrol. Earth Syst. Sci. Discuss., 19, 14705-14745, https://doi.org/10.5194/hessd-10-14705-2013, 2013.

Balsamo, G., Albergel, C., Beljaars, A., Boussetta, S., Brun, E., Cloke, H., Dee, D., Dutra, E., Muñoz-Sabater, J., Pappenberger, F., de Rosnay, P., Stockdale, T., and Vitart, F.: ERAInterim/Land: a global land surface reanalysis data set, Hydrol. Earth Syst. Sci., 19, 389-407, https://doi.org/10.5194/hess-19389-2015, 2015.

Barnett, T. P., Adam, J. C., and Lettenmaier, D. P.: Potential impacts of a warming climate on water availability in snow-dominated regions, Nature, 438, 303-309, 2005.

Beniston, M.: Climatic change in mountain regions: a review of possible impacts, in: Climate variability and change in high elevation regions: Past, present \& future, Springer, 5-31, 2003.

Beniston, M. and Stoffel, M.: Assessing the impacts of climatic change on mountain water resources, Sci. Total Environ., 493, 1129-1137, 2014.

Beniston, M., Uhlmann, B., Goyette, S., and Lopez-Moreno, J. I.: Will snow-abundant winters still exist in the Swiss Alps in an enhanced greenhouse climate?, Int. J. Climatol., 31, 1257-1263, 2011.

Bentsen, M., Bethke, I., Debernard, J. B., Iversen, T., Kirkevåg, A., Seland, Ø., Drange, H., Roelandt, C., Seierstad, I. A., Hoose, C., and Kristjánsson, J. E.: The Norwegian Earth Sys- tem Model, NorESM1-M - Part 1: Description and basic evaluation of the physical climate, Geosci. Model Dev., 6, 687-720, https://doi.org/10.5194/gmd-6-687-2013, 2013.

Bi, D., Dix, M., Marsl, S., O'Farrell, S., Rashid, H., Uotila, P., Hirst, A., Kowalczyk, E., Golebiewski, M., Sullivan, A., and Yan, H.: The ACCESS coupled model: Description, control climate and evaluation, Aust. Met. Oceanog. J., 63, 9-32, 2013.

Brown, R., Derksen, C., and Wang, L.: A multi-data set analysis of variability and change in Arctic spring snow cover extent, 1967-2008, J. Geophys. Res.-Atmos., 115, D16111, https://doi.org/10.1029/2010JD013975, 2010.

Brun, E., Vionnet, V., Boone, A., Decharme, B., Peings, Y., Valette, R., Karbou, F., and Morin, S.: Simulation of northern eurasian local snow depth, mass, and density using a detailed snowpack model and meteorological reanalyses, J. Hydrometeorol., 14, 203-219, 2013.

CDO: CDO 2015: Climate Data Operators, available at: http://www. mpimet.mpg.de/cdo (last access: December 2016), 2015.

Chimani, B., Böhm, R., Matulla, C., and Ganekind, M.: Development of a longterm dataset of solid/liquid precipitation, Adv. Sci. Res., 6, 39-43, https://doi.org/10.5194/asr-6-39-2011, 2011.

Christensen, O. B., Drews, M., Hesselbjerg Christensen, J., Dethloff, K., Ketelsen, K., Hebestadt, I., and Rinke, A.: The HIRHAM Regional Climate Model. Version 5 (beta), Tech. rep., Danish Climate Centre, Danish Meteorological Institute, 2007.

Clifford, D.: Global estimates of snow water equivalent from passive microwave instruments: history, challenges and future developments, International J. Remote Sens., 31, 3707-3726, 2010.

Collier, M., Jeffrey, S., Rotstayn, L., Wong, K., Dravitzki, S., Moseneder, C., Hamalainen, C., Syktus, J., Suppiah, R., Antony, J., El Zeind, A., and Atif, M.: The CSIRO-Mk3. 6.0 AtmosphereOcean GCM: participation in CMIP5 and data publication, in: International Congress on Modelling and Simulation-MODSIM 2011, 2011.

Collins, M., Tett, S., and Cooper, C.: The internal climate variability of HadCM3, a version of the Hadley Centre coupled model without flux adjustments, Clim. Dynam., 17, 61-81, 2001.

Collins, W. J., Bellouin, N., Doutriaux-Boucher, M., Gedney, N., Halloran, P., Hinton, T., Hughes, J., Jones, C. D., Joshi, M., Liddicoat, S., Martin, G., O'Connor, F., Rae, J., Senior, C., Sitch, S., Totterdell, I., Wiltshire, A., and Woodward, S.: Development and evaluation of an Earth-System model - HadGEM2, Geosci. Model Dev., 4, 1051-1075, https://doi.org/10.5194/gmd-4-10512011, 2011.

Compo, G. P., Whitaker, J. S., Sardeshmukh, P. D., Matsui, N., Allan, R. J., Yin, X., Gleason, B. E., Vose, R. S., Rutledge, G., Bessemoulin, P., Brönnimann, S., Brunet, M., Crouthamel, R. I., Grant, A. N., Groisman, P. Y., Jones, P. D., Kruk, M. C., Kruger, A. C., Marshall, G. J., Maugeri, M., Mok, H. Y., Nordli, O., Ross, T. F., Trigo, R. M., Wang, X. L., Woodruff, S. D., and Worley, S. J.: The Twentieth Century Reanalysis Project, Q. J. Roy. Meteor. Soc., 137, 1-28, https://doi.org/10.1002/qj.776, 2011.

Davini, P., von Hardenberg, J., Corti, S., Christensen, H. M., Juricke, S., Subramanian, A., Watson, P. A. G., Weisheimer, A., and Palmer, T. N.: Climate SPHINX: evaluating the impact of resolution and stochastic physics parameterisations in the ECEarth global climate model, Geosci. Model Dev., 10, 1383-1402, https://doi.org/10.5194/gmd-10-1383-2017, 2017. 
Dee, D. P., Uppala, S. M., Simmons, A. J., Berrisford, P., Poli, P., Kobayashi, S., Andrae, U., Balmaseda, M. A., Balsamo, G., Bauer, P., Bechtold, P., Beljaars, A. C. M., van de Berg, L., Bidlot, J., Bormann, N., Delsol, C., Dragani, R., Fuentes, M., Geer, A. J., Haimberger, L., Healy, S. B., Hersbach, H., Hólm, E. V., Isaksen, L., Kållberg, P., Köhler, M., Matricardi, M., McNally, A. P., Monge-Sanz, B. M., Morcrette, J.-J., Park, B.-K., Peubey, C., de Rosnay, P., Tavolato, C., Thépaut, J.-N., and Vitart, F.: The ERA-Interim reanalysis: configuration and performance of the data assimilation system, Q. J. Roy. Meteor. Soc., 137, 553-597, https://doi.org/10.1002/qj.828, 2011.

Delworth, T. L., Broccoli, A. J., Rosati, A., Stouffer, R. J., Balaji, V., Beesley, J. A., Cooke, W. F., Dixon, K. W., Dunne, J., Dunne, K., Durachta, J. W., Findell, K. L., Ginoux, P., Gnanadesikan, A., Gordon, C. T., Griffies, S. M., Gudgel, R., Harrison, M. J., Held, I. M., Hemler, R. S., Horowitz, L. W., Klein, S. A., Knutson, T. R., Kushner, P. J., Langenhorst, A. R., Lee, H.-C., Lin, S.-J., Lu, J., Malyshev, S. L., Milly, P. C. D., Ramaswamy, V., Russell, J., Schwarzkopf, M. D., Shevliakova, E., Sirutis, J. J., Spelman, M. J., Stern, W. F., Winton, M., Wittenberg, A. T., Wyman, B., Zeng, F., and Zhang, R.: GFDL's CM2 global coupled climate models. Part I: Formulation and simulation characteristics, J. Climate, 19, 643-674, 2006.

Diffenbaugh, N. S., Scherer, M., and Ashfaq, M.: Response of snow-dependent hydrologic extremes to continued global warming, Nature Climate Change, 3, 379-384, 2013.

Donner, L. J., Wyman, B. L., Hemler, R. S., Horowitz, L. W., Ming, Y., Zhao, M., Golaz, J.-C., Ginoux, P., Lin, S.-J., Schwarzkopf, M. D., Austin, J., Alaka, G., Cooke, W. F., Delworth, T. L., Freidenreich, S. M., Gordon, C. T., Griffies, S. M., Held, I. M., Hurlin, W. J., Klein, S. A., Knutson, T. R., Langenhorst, A. R., Lee, H.-C., Lin, Y., Magi, B. I., Malyshev, S. L., Milly, P. C. D., Naik, V., Nath, M. J., Pincus, R., Ploshay, J. J., Ramaswamy, V., Seman, C. J., Shevliakova, E., Sirutis, J. J., Stern, W. F., Stouffer, R. J., Wilson, R. J., Winton, M., Wittenberg, A. T., and Zeng, F.: The dynamical core, physical parameterizations, and basic simulation characteristics of the atmospheric component AM3 of the GFDL global coupled model CM3, J. Climate, 24, 3484-3519, 2011

Dunne, J. P., John, J. G., Adcroft, A. J., Griffies, S. M., Hallberg, R. W., Shevliakova, E., Stouffer, R. J., Cooke, W., Dunne, K. A., Harrison, M. J., Krasting, J. P., Malyshev, S. L., Milly, P. C. D., Phillipps, P. J., Sentman, L. T., Samuels, B. L., Spelman, M. J., Winton, M., Wittenberg, A. T., and Zadeh, N.: GFDL's ESM2 global coupled climate-carbon Earth System Models. Part I: Physical formulation and baseline simulation characteristics, J. Climate, 25, 6646-6665, 2012.

Dutra, E., Balsamo, G., Viterbo, P., Miranda, P. M., Beljaars, A., Schär, C., and Elder, K.: An improved snow scheme for the ECMWF land surface model: description and offline validation, J. Hydrometeor., 11, 899-916, https://doi.org/10.1175/2010jhm1249.1, 2010.

Farda, A., Déué, M., Somot, S., Horányi, A., Spiridonov, V., and Tóth, H.: Model ALADIN as regional climate model for Central and Eastern Europe, Stud. Geophys. Geod., 54, 313-332, 2010.

Gan, T. Y., Barry, R. G., and Gobena, A. K.: Changes in Snowpacks of Canadian Prairies for 1979-2004 Detected from Snow Water Equivalent Data of SMMR and SSM/I Passive Microwave and
Related Climatic Factors, Remote Sensing of the Terrestrial Water Cycle, 206, 227-231, 2014.

Gent, P. R., Danabasoglu, G., Donner, L. J., Holland, M. M., Hunke, E. C., Jayne, S. R., Lawrence, D. M., Neale, R. B., Rasch, P. J., Vertenstein, M., Worley, P. H., Yang, Z., and Zhang, M.: The Community Climate System Model Version 4., J. Climate, 24, 4973-4991, https://doi.org/10.1175/2011jcli4083.1, 2011.

Giorgetta, M. A., Jungclaus, J., Reick, C. H., Legutke, S., Bader, J., Böttinger, M., Brovkin, V., Crueger, T., Esch, M., Fieg, K., Glushak, K., Gayler, V., Haak, H., Hollweg, H.-D., Ilyina, T., Kinne, S., Kornblueh, L., Matei, D., Mauritsen, T., Mikolajewicz, U., Mueller, W., Notz, D., Pithan, F., Raddatz, T., Rast, S., Redler, R., Roeckner, E., Schmidt, H., Schnur, R., Segschneider, J., Six, K. D., Stockhause, M., Timmreck, C., Wegner, J., Widmann, H., Wieners, K.-H., Claussen, M., Marotzke, J., and Stevens, B.: Climate and carbon cycle changes from 1850 to 2100 in MPI-ESM simulations for the Coupled Model Intercomparison Project phase 5, J. Adv. Model. Earth Syst., 5, 572-597, https://doi.org/10.1002/jame.20038, 2013.

Gordon, C., Cooper, C., Senior, C. A., Banks, H., Gregory, J. M., Johns, T. C., Mitchell, J. F., and Wood, R. A.: The simulation of SST, sea ice extents and ocean heat transports in a version of the Hadley Centre coupled model without flux adjustments, Clim. Dynam., 16, 147-168, 2000.

Haarsma, R. J., Roberts, M., Vidale, P. L., Senior, C. A., Bellucci, A., Bao, Q., Chang, P., Corti, S., Fučkar, N. S., Guemas, V., von Hardenberg, J., Hazeleger, W., Kodama, C., Koenigk, T., Leung, L. R., Lu, J., Luo, J.-J., Mao, J., Mizielinski, M. S., Mizuta, R., Nobre, P., Satoh, M., Scoccimarro, E., Semmler, T., Small, J., and von Storch, J.-S.: High Resolution Model Intercomparison Project (HighResMIP), Geoscientific Model Development Discussions, 2016, 1-35, https://doi.org/10.5194/gmd-2016-66, 2016.

Hagemann, S.: An improved land surface parameter dataset for global and regional climate models, Tech. Rep. 336, MaxPlanck-Institut für Meteorologie, http://hdl.handle.net/11858/ 00-001M-0000-002B-539B-6, 2002.

Hall, D. K. and Riggs, G. A.: Accuracy assessment of the MODIS snow products, Hydrol. Process., 21, 1534-1547, 2007.

Hancock, S., Baxter, R., Evans, J., and Huntley, B.: Evaluating global snow water equivalent products for testing land surface models, Remote Sens. Environ., 128, 107-117, 2013.

Hantel, M., Maurer, C., and Mayer, D.: The snowline climate of the Alps 1961-2010, Theor. Appl. Climatol., 110, 517-537, 2012.

Hastings, D. and Dunbar, P.: Global Land One-kilometer Base Elevation (GLOBE) Digital Elevation Model, Documentation, Volume 1.0. Key to Geophysical Records Documentation (KGRD) 34, 1999.

Haylock, M., Hofstra, N., Klein Tank, A., Klok, E., Jones, P., and New, M.: A European daily high-resolution gridded data set of surface temperature and precipitation for 1950-2006, J. Geophys. Res.-Atmos., 113, https://doi.org/doi:10.1029/2008JD010201, 2008.

Hazeleger, W., Wang, X., Severijns, C., Ştefănescu, S., Bintanja, R., Sterl, A., Wyser, K., Semmler, T., Yang, S., and Van den Hurk, B.: EC-Earth V2. 2: description and validation of a new seamless earth system prediction model, Climate Dyn., 39, 2611-2629, https://doi.org/10.1007/s00382-011-1228-5, 2012. 
Hurrell, J. W., Holland, M., Gent, P., Ghan, S., Kay, J. E., Kushner, P., Lamarque, J.-F., Large, W., Lawrence, D., Lindsay, K., Lipscomb, W. H., Long, M. C., Mahowald, N., Marsh, D. R., Neale, R. B., Rasch, P., Vavrus, S., Vertenstein, M., Bader, D., Collins, W. D., Hack, J. J., Kiehl, J., and Marshall, S.: The Community Earth System Model: A Framework for Collaborative Research, B. Am. Meteorol. Soc., 94, 1339-1360, https://doi.org/10.1175/BAMS-D-12-00121.1, 2013.

Imperio, S., Bionda, R., Viterbi, R., and Provenzale, A.: Climate change and human disturbance can lead to local extinction of Alpine rock ptarmigan: New insight from the Western Italian Alps, PloS one, 8, e81598, https://doi.org/10.1371/journal.pone.0081598, 2013.

IPCC: Climate Change 2013: The Physical Science Basis: Working Group I Contribution to the Fifth Assessment Report of the Intergovernmental Panel on Climate Change, Cambridge University Press, 2013.

Jacob, D. and Podzun, R.: Sensitivity studies with the regional climate model REMO, Meteorol. Atmos. Phys., 63, 119-129, 1997.

Jacob, D., Petersen, J., Eggert, B., Alias, A., Christensen, O. B., Bouwer, L. M., Braun, A., Colette, A., Déqué, M., Georgievski, G., Georgopoulou, E., Gobiet, A., Menut, L., Nikulin, G., Haensler, A., Hempelmann, N., Jones, C., Keuler, K., Kovats, S., Kröner, N., Kotlarski, S. , Kriegsmann, A., Martin, E., van Meijgaard, E., Moseley, C., Pfeifer, S., Preuschmann, S., Radermacher, C., Radtke, K., Rechid, D., Rounsevell, M., Samuelsson, P., Somot, S., Soussana, J. F., Teichmann, C., Valentini, R., Vautard, R., Weber, B., and Yiou, P.: EURO-CORDEX: new highresolution climate change projections for European impact research, Reg. Environ. Change, 14, 563-578, 2014.

Johns, T., Gregory, J., Ingram, W., Johnson, C., Jones, A., Lowe, J., Mitchell, J., Roberts, D., Sexton, D., Stevenson, D., Tett, S., and Woodage, M.: Anthropogenic climate change for 1860 to 2100 simulated with the HadCM3 model under updated emissions scenarios, Clim. Dynam., 20, 583-612, https://doi.org/10.1007/s00382-002-0296-y, 2003.

Jones, P. W.: First-and second-order conservative remapping schemes for grids in spherical coordinates, Mon. Weather Rev., 127, 2204-2210, 1999.

Kopp, T. and Kiess, R.: The air force global weather central snow analysis model, in: Conference on weather analysis and forecasting, vol. 15, 220-222, American Meteorological Society, 1996.

Körner, C.: Alpine plant life: functional plant ecology of high mountain ecosystems, Springer Science \& Business Media, 2003.

Koster, R. D., Suarez, M. J., Ducharne, A., Stieglitz, M., and Kumar, P.: A Catchment-Based Approach to Modeling Land Surface Processes in a GCM. Part 1; Model Structure, J. Geophys. Res., 105, 24809-24822, 2000.

Kotlarski, S., Keuler, K., Christensen, O. B., Colette, A., Déqué, M., Gobiet, A., Goergen, K., Jacob, D., Lüthi, D., van Meijgaard, E., Nikulin, G., Schär, C., Teichmann, C., Vautard, R., Warrach-Sagi, K., and Wulfmeyer, V.: Regional climate modeling on European scales: a joint standard evaluation of the EUROCORDEX RCM ensemble, Geosci. Model Dev., 7, 1297-1333, https://doi.org/10.5194/gmd-7-1297-2014, 2014.

Li, L., Lin, P., Yu, Y., Wang, B., Zhou, T., Liu, L., Liu, J., Bao, Q., Xu, S., Huang, W., Xia, K., Pu, Y., Dong, L., Shen, S., Liu, Y., Hu, N., Liu, M., Sun, W., Shi, X., Zheng, W., Wu, B., Song,
M., Liu, H., Zhang, X., Wu, G., Xue, W., Huang, X., Yang, G., Song, Z., and Qiao, F.: The flexible global ocean-atmosphereland system model, Grid-point Version 2: FGOALS-g2, Adv. Atmos. Sci., 30, 543-560, https://doi.org/10.1007/s00376-0122140-6, 2013.

Meng, J., Yang, R., Wei, H., Ek, M., Gayno, G., Xie, P., and Mitchell, K.: The land surface analysis in the NCEP Climate Forecast System Reanalysis, J. Hydrometeor., 13, 1621-1630, 2012.

Moss, R. H., Edmonds, J. A., Hibbard, K. A., Manning, M. R., Rose, S. K., van Vuuren, D. P., Carter, T. R., Emori, S., Kainuma, M., Kram, T., Meehl, G. A., Mitchell, J. F. B., Nakicenovic, N., Riahi, K., Smith, S. J., Stouffer, R. J., Thomson, A. M., Weyant, J. P., and Wilbanks, T. J.: The next generation of scenarios for climate change research and assessment, Nature, 463, 747-756, https://doi.org/10.1038/nature08823, 2010.

Mudryk, L., Derksen, C., Kushner, P., and Brown, R.: Characterization of Northern Hemisphere snow water equivalent datasets, 1981-2010, J. Climate, 28, 8037-8051, 2015.

Qiao, F., Song, Z., Bao, Y., Song, Y., Shu, Q., Huang, C., and Zhao, W.: Development and evaluation of an Earth System Model with surface gravity waves, J. Geophys. Res.-Oceans, 118, 45144524, https://doi.org/10.1002/jgrc.20327, 2013.

Rienecker, M. M., Suarez, M. J., Gelaro, R., Todling, R., Bacmeister, J., Liu, E., Bosilovich, M. G., Schubert, S. D., Takacs, L., Kim, G.-K., Bloom, S., Chen, J., Collins, D., Conaty, A., da Silva, A., Gu, W., Joiner, J., Koster, R. D., Lucchesi, R., Molod, A., Owens, T., Pawson, S., Pegion, P., Redder, C. R., Reichle, R., Robertson, F. R., Ruddick, A. G., Sienkiewicz, M., and Woollen, J.: MERRA: NASA's modern-era retrospective analysis for research and applications, J. Climate, 24, 3624-3648, 2011.

Rixen, C., Teich, M., Lardelli, C., Gallati, D., Pohl, M., Pütz, M., and Bebi, P.: Winter tourism and climate change in the Alps: an assessment of resource consumption, snow reliability, and future snowmaking potential, Mt. Res. Dev., 31, 229-236, 2011.

Rockel, B., Will, A., and Hense, A.: The regional climate model COSMO-CLM (CCLM), Meteorol. Z., 17, 347-348, 2008.

Sabin, T., Krishnan, R., Ghattas, J., Denvil, S., Dufresne, J.-L., Hourdin, F., and Pascal, T.: High resolution simulation of the South Asian monsoon using a variable resolution global climate model, Clim. Dynam., 41, 173-194, 2013.

Saha, S., Moorthi, S., Pan, H.-L., Wu, X., Wang, J., Nadiga, S., Tripp, P., Kistler, R., Woollen, J., Behringer, D., et al.: The NCEP Climate Forecast System Reanalysis, B. Am. Meteorol. Soc, 91, 1015-1057, https://doi.org/10.1175/2010BAMS3001.1, 2010.

Salzmann, N., Huggel, C., Rohrer, M., and Stoffel, M.: Data and knowledge gaps in glacier, snow and related runoff research - A climate change adaptation perspective, J. Hydrol., 518, 225-234, 2014.

Scherrer, S., Ceppi, P., Croci-Maspoli, M., and Appenzeller, C.: Snow-albedo feedback and Swiss spring temperature trends, Theor. Appl. Climatol., 110, 509-516, 2012.

Schmidt, G. A., Ruedy, R., Hansen, J. E., Aleinov, I., Bell, N., Bauer, M., Bauer, S., Cairns, B., Canuto, V., Cheng, Y., Genio, A. D., Faluvegi, G., Friend, A. D., Hall, T. M., Hu, Y., Kelley, M., Kiang, N. Y., Koch, D., Lacis, A. A., Lerner, J., Lo, K. K., Miller, R. L., Nazarenko, L., Oinas, V., Perlwitz, J., Perlwitz, J., Rind, D., Romanou, A., Russell, G. L., Sato, M., Shindell, D. T., Stone, P. H., Sun, S., Tausnev, N., Thresher, D., and Yao, M.-S.: 
Present-day atmospheric simulations using GISS ModelE: Comparison to in situ, satellite, and reanalysis data, J. Climate, 19, 153-192, https://doi.org/10.1175/JCLI3612.1, 2006.

Scoccimarro, E., Gualdi, S., Bellucci, A., Sanna, A., Giuseppe Fogli, P., Manzini, E., Vichi, M., Oddo, P., and Navarra, A.: Effects of tropical cyclones on ocean heat transport in a high-resolution coupled general circulation model, J. Climate, 24, 4368-4384, https://doi.org/10.1175/2011jcli4104.1, 2011.

Serquet, G., Marty, C., Dulex, J.-P., and Rebetez, M.: Seasonal trends and temperature dependence of the snowfall/precipitationday ratio in Switzerland, Geophys. Res. Lett., 38, https://doi.org/10.1029/2011GL046976, 2011.

Steger, C., Kotlarski, S., Jonas, T., and Schär, C.: Alpine snow cover in a changing climate: a regional climate model perspective, Clim. Dynam., 41, 735-754, 2013.

Stewart, I. T.: Changes in snowpack and snowmelt runoff for key mountain regions, Hydrol. Process., 23, 78-94, 2009.

Stieglitz, M., Ducharne, A., Koster, R., and Suarez, M.: The impact of detailed snow physics on the simulation of snow cover and subsurface thermodynamics at continental scales, J. Hydrometeor., 2, 228-242, 2001.

Takala, M., Luojus, K., Pulliainen, J., Derksen, C., Lemmetyinen, J., Kärnä, J.-P., Koskinen, J., and Bojkov, B.: Estimating northern hemisphere snow water equivalent for climate research through assimilation of space-borne radiometer data and ground-based measurements, Remote Sens. Environ., 115, 3517-3529, 2011.

Taylor, K. E.: Summarizing multiple aspects of model performance in a single diagram, J. Geophys. Res.-Atmos., 106, 7183-7192, 2001.

Taylor, K. E., Stouffer, R. J., and Meehl, G. A.: An overview of CMIP5 and the experiment design, B. Am. Meteorol. Soc., 93, 485-498, https://doi.org/10.1175/BAMS-D-11-00094.1, 2012.

Tedesco, M., Kelly, R., Foster, J., and Chang, A.: AMSR-E/Aqua Daily L3 Global Snow Water Equivalent EASE-Grids. Version 2. [2002-2011]. Boulder, Colorado USA: NASA National Snow and Ice Data Center Distributed Active Archive Center, https://doi.org/10.5067/AMSR-E/AE_DYSNO.002, 2004.

Terzago, S., von Hardenberg, J., Palazzi, E., and Provenzale, A.: Snowpack changes in the Hindu-Kush Karakoram Himalaya from CMIP5 Global Climate Models, J. Hydrometeorol., 15, 2293-2313, https://doi.org/10.1175/JHM-D-13-0196.1, 2014.

Tong, J. and Velicogna, I.: A comparison of AMSR-E/Aqua snow products with in situ observations and MODIS snow cover products in the Mackenzie River Basin, Canada, Remote Sensing, 2, 2313-2322, 2010.

Uppala, S. M., Kållberg, P., Simmons, A., Andrae, U., Bechtold, V. d., Fiorino, M., Gibson, J., Haseler, J., Hernandez, A., Kelly, G., Li, X., Onogi, K., Saarinen, S., Sokka, N., Allan, R. P., Andersson, E., Arpe, K., Balmaseda, M. A., Beljaars, A. C. M., Berg, L. V. D., Bidlot, J., Bormann, N., Caires, S., Chevallier, F., Dethof, A., Dragosavac, M., Fisher, M., Fuentes, M., Hagemann, S., Hólm, E., Hoskins, B. J., Isaksen, L., Janssen, P. A. E. M., Jenne, R., Mcnally, A. P., Mahfouf, J.-F., Morcrette, J.-J., Rayner, N. A., Saunders, R. W., Simon, P., Sterl, A., Trenberth, K. E., Untch, A., Vasiljevic, D., Viterbo, P., and Woollen, J.: : The ERA-40 re-analysis, Q. J. Roy. Meteor. Soc., 131, 2961-3012, 2005. van den Hurk, B., Kim, H., Krinner, G., Seneviratne, S. I., Derksen, C., Oki, T., Douville, H., Colin, J., Ducharne, A., Cheruy, F., Viovy, N., Puma, M. J., Wada, Y., Li, W., Jia, B., Alessandri, A., Lawrence, D. M., Weedon, G. P., Ellis, R., Hagemann, S., Mao, J., Flanner, M. G., Zampieri, M., Materia, S., Law, R. M., and Sheffield, J.: LS3MIP (v1.0) contribution to CMIP6: the Land Surface, Snow and Soil moisture Model Intercomparison Project - aims, setup and expected outcome, Geosci. Model Dev., 9, 2809-2832, https://doi.org/10.5194/gmd-9-2809-2016, 2016.

Van Meijgaard, E., Van Ulft, L., Lenderink, G., De Roode, S., Wipfler, E. L., Boers, R., and van Timmermans, R.: Refinement and application of a regional atmospheric model for climate scenario calculations of Western Europe, KVR 054/12, KVR, 2012.

Voldoire, A., Sanchez-Gomez, E., Salas y Mélia, D., Decharme, B., Cassou, C., Sénési, S., Valcke, S., Beau, I., Alias, A., Chevallier, M., Déqué, M., Deshayes, J., Douville, H., Fernandez, E., Madec, G., Maisonnave, E., Moine, M.-P., Planton, S., Saint-Martin, D., Szopa, S., Tyteca, S., Alkama, R., Belamari, S., Braun, A., Coquart, L., and Chauvin, F.: The CNRMCM5.1 global climate model: description and basic evaluation, Clim. Dynam., 40, 2091-2121, https://doi.org/10.1007/s00382011-1259-y, 2013.

Volodin, E., Dianskii, N., and Gusev, A.: Simulating present-day climate with the INMCM4.0 coupled model of the atmospheric and oceanic general circulations, Atmos. Ocean. Phys., 46, 414 431, https://doi.org/10.1134/s000143381004002x, 2010.

Wu, T., Li, W., Ji, J., Xin, X., Li, L., Wang, Z., Zhang, Y., Li, J., Zhang, F., Wei, M., Shi, X., Wu, F., Zhang, L., Chu, M., Jie, W., Liu, Y., Wang, F., Liu, X., Li, Q., Dong, M., Liang, X., Gao, Y., and Zhang, J.: Global carbon budgets simulated by the Beijing Climate Center Climate System Model for the last century, J. Geophys. Res.-Atmos., 118, 4326-4347, https://doi.org/10.1002/jgrd.50320, 2013.

Yukimoto, S., Adachi, Y., and Hosaka, M.: A new global climate model of the Meteorological Research Institute: MRICGCM3: model description and basic performance (special issue on recent development on climate models and future climate projections), J. Meteorol. Soc. Jpn., 90, 23-64, https://doi.org/10.2151/jmsj.2012-a02, 2012. 